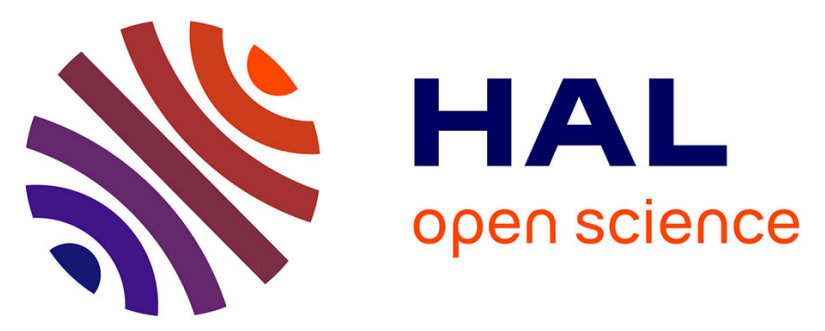

\title{
Insights on nitrogen and phosphorus co-limitation in global croplands from theoretical and modelling fertilization experiments
}

Bruno Ringeval, Marko Kvakić, Laurent Augusto, Philippe Ciais, Daniel Goll, Nathaniel Mueller, Christoph Müller, Thomas Nesme, Nicolas Vuichard, Xuhui Wang, et al.

\section{To cite this version:}

Bruno Ringeval, Marko Kvakić, Laurent Augusto, Philippe Ciais, Daniel Goll, et al.. Insights on nitrogen and phosphorus co-limitation in global croplands from theoretical and modelling fertilization experiments. Global Biogeochemical Cycles, 2021, 35 (6), pp.e2020GB006915. 10.1029/2020GB006915 . hal-03235586

\author{
HAL Id: hal-03235586 \\ https://hal.science/hal-03235586
}

Submitted on 8 Jul 2021

HAL is a multi-disciplinary open access archive for the deposit and dissemination of scientific research documents, whether they are published or not. The documents may come from teaching and research institutions in France or abroad, or from public or private research centers.
L'archive ouverte pluridisciplinaire HAL, est destinée au dépôt et à la diffusion de documents scientifiques de niveau recherche, publiés ou non, émanant des établissements d'enseignement et de recherche français ou étrangers, des laboratoires publics ou privés. 
Global

Biogeochemical Cycles

\author{
RESEARCH ARTICLE \\ 10.1029/2020GB006915 \\ Key Points: \\ - Synergistic N and P co-limitation \\ could occur even using the Liebig's \\ law of minimum as the formalism of \\ nutrient interaction \\ - By assuming the multiple limitation \\ hypothesis, a true co-limitation \\ could affect $\sim 40 \%$ of the global \\ maize area
}

Supporting Information:

Supporting Information may be found in the online version of this article.

Correspondence to:

B. Ringeval,

bruno.ringeval@inrae.fr

Citation:

Ringeval, B., Kvakić, M., Augusto, L., Ciais, P., Goll, D. S., Mueller, N. D., et al. (2021). Insights on nitrogen and phosphorus co-limitation in global croplands from theoretical and modeling fertilization experiments. Global Biogeochemical Cycles, 35, e2020GB006915. https://doi. org/10.1029/2020GB006915

Received 10 DEC 2020

Accepted 7 MAY 2021

Author Contributions:

Conceptualization: Bruno Ringeval Methodology: Bruno Ringeval, Marko Kvakić, Laurent Augusto, Daniel S. Goll, Nathaniel D. Mueller, Christoph Müller, Thomas Nesme, Nicolas Vuichard, Sylvain Pellerin

Resources: Nathaniel D. Mueller, Christoph Müller, Xuhui Wang Software: Bruno Ringeval, Marko Kvakić

Writing - original draft: Bruno Ringeval

Writing - review \& editing: Marko Kvakić, Laurent Augusto, Philippe Ciais, Daniel S. Goll, Nathaniel D. Mueller, Christoph Müller, Thomas Nesme, Nicolas Vuichard, Sylvain Pellerin

(c) 2021. American Geophysical Union. All Rights Reserved.

\section{Insights on Nitrogen and Phosphorus Co-Limitation in Global Croplands From Theoretical and Modeling Fertilization Experiments}

\author{
Bruno Ringeval $^{1}$ (D), Marko Kvakic ${ }^{1,2}$ (D), Laurent Augusto' ${ }^{1}$, Philippe Ciais ${ }^{2}$, \\ Daniel S. Goll ${ }^{2}$ (D), Nathaniel D. Mueller ${ }^{3,4}$ (D) Christoph Müller ${ }^{5}$ (D), Thomas Nesme', \\ Nicolas Vuichard ${ }^{2}$ (D), Xuhui Wang ${ }^{6}$, and Sylvain Pellerin ${ }^{1}$
}

${ }^{1}$ ISPA, Bordeaux Sciences Agro, INRAE, Villenave d'Ornon, France, ${ }^{2}$ Laboratoire de Sciences du Climat et de l'Environnement, LSCE/IPSL, CEA-CNRS-UVSQ, Universite Paris-Saclay, Gif-Sur-Yvette, France, ${ }^{3}$ Department of Ecosystem Science and Sustainability, Colorado State University, Fort Collins, CO, USA, ${ }^{4}$ Department of Soil and Crop Sciences, Colorado State University, Fort Collins, CO, USA, ${ }^{5}$ Potsdam Institute for Climate Impact Research, Member of the Leibniz Association, Potsdam, Germany, ${ }^{6}$ Sino-French Institute of Earth System Sciences, Peking University, Beijing, China

\begin{abstract}
Single and combined fertilization additions are a common tool to assess the interactions between nutrients in a given ecosystem. While such experiments can allow systems to be defined into categories of nutrient interactions, for example, simultaneous co-limitation or single resource response, this categorization may itself be sensitive to way nutrient interactions are mathematically formulated. To this end, we developed a theoretical analysis of nitrogen $(\mathrm{N})$ and phosphorus $(\mathrm{P})$ fertilization experiments based on the computation of ratios between plant demand and soil supply for each nutrient to explore two mathematical interaction formalisms: Liebig's law of minimum (LM) and the multiple limitation hypothesis $(\mathrm{MH})$. We defined, for each interaction formalism, what conditions (in terms of supply and demand in $\mathrm{N}$ and $\mathrm{P}$ ) are required to make the ecosystem in each category of nutrient interaction. Notably, we showed that synergistic co-limitation could occur even using LM formalism under certain conditions. We then applied our framework to global maps of soil nutrient supply and of crop nutrient demand to achieve the potential yield. This was done to examine how the choice of interaction formalism influenced the occurrence of nutrient interaction categories. $\mathrm{MH}$ predicts true co-limitation for $\sim 40 \%$ of the global maize area where LM predicts other categories of nutrient interaction, particularly single resource $\mathrm{P}$ limitation (whose the exact occurrence is, however, sensitive to the amount of $\mathrm{P}$ applied in the fertilization experiments). Our study identified areas where real fertilization experiments are required to choose between LM or MH to best represent nutrient interaction in croplands.
\end{abstract}

\section{Introduction}

In global assessments of crop ecosystem productivity limitations by nutrients, nitrogen (N) and phosphorus (P) are sometimes considered independently (Peñuelas et al., 2013); or they are considered together but without focusing on how the interaction modulates the limitation (Mueller et al., 2012). N and P cycles interact strongly with different processes that are key to this coupling (Achat et al., 2016). The most commonly studied interaction is related to the limitation of plant growth by nutrients: an increase in organ biomass (mainly composed of carbon, $\mathrm{C}$ ) requires a given amount of both $\mathrm{N}$ and $\mathrm{P}$, to respect stoichiometric constraints. The interaction between $\mathrm{C}$ and nutrients is usually represented by $\mathrm{C}$ :nutrient ratios for each organ. Plant growth is assumed to be limited when the demand for nutrients, estimated from C:nutrient ratios and $\mathrm{C}$ available for potential growth, is not satisfied by the supply of nutrient taken up by the plant. Due to incomplete knowledge about the mechanisms at the basis of the interaction and how these mechanisms are combined when integrating spatial scales and levels of organization (plant organ, individual, community, ecosystem) (Ågren et al., 2012; Davidson A. Eric \& Howarth W. Robert, 2007; De Wit, 1992; Sistla \& Schimel, 2012), the characterization of multiple element limitation remains an open scientific question. Two formalisms are generally used: Liebig's law of the minimum (LM) or the multiple limitation hypothesis (MH). In LM, plants are assumed to be limited by a single nutrient at a time, with potential release of the nutrient in excess. In MH, it is assumed that plants adjust their growth patterns and thus they are co-limited 
by multiple nutrients simultaneously (奋ren et al., 2012). The MH formalism thus assumes that plants will mine the least available nutrient by using other resources. For instance, plants growing in an ecosystem with a P-poor soil will invest $\mathrm{C}$ and $\mathrm{N}$ in the root system (Ryan \& Graham, 2018) to access more P (Davidson $\&$ Howarth, 2007). These investments can take place trough increase in root growth and activity, increase in phosphatase production or fungal mycorrhizae that form symbioses with plant roots and increase in recycling of $\mathrm{P}$ within plants (Ryan \& Graham, 2018). Both formalisms (LM or MH) could be considered as macro-properties that reflect the same plant adjustments processes but, depending on the conditions, those adjustments may lead to an emerging behavior that verifies one or the other formalism (Ågren et al., 2012). The further the supply of an essential nutrient deviates from a conceptual and theoretical optimum stoichiometry of plants, the more plants will follow the LM formalism (Ågren et al., 2012). LM is commonly assumed in many studies and is for instance used in most large-scale models dealing with multiple nutrient limitations (Barros et al., 2004; Folberth et al., 2019; Goll et al., 2012; Mueller et al., 2012). Despite the representation of some flexibility in allocation and stoichiometry (leading to some flexibility in nutrient requirements), land surface models still apply LM or MH to regulate growth of new tissues (Davies-Barnard et al., 2020).

One way to assess the current nutrient limitation empirically is to provide one-time applications of $+\mathrm{N}$, $+\mathrm{P}$ and $+\mathrm{NP}$ and to measure the increase in ecosystem productivity as compared to a control trial without any application. Such experiments are usually called fertilization experiments. By definition (Harpole et al., 2011), there is a true NP co-limitation when the ecosystem is observed to respond to combined $\mathrm{N}$ and $\mathrm{P}$ addition only, or to both $\mathrm{N}$ and $\mathrm{P}$ when added separately. Such co-limitations are (in most cases) synergistic, that is, the response to $+\mathrm{NP}$ is strictly greater than the sum of the responses to $+\mathrm{N}$ alone and $+\mathrm{P}$ alone. A co-limitation cannot be qualified of true (and in that case, is only synergistic) when the ecosystem is insensitive to the addition of one nutrient alone while sensitive to the other one. The different categories of nutrient limitation are summarized in Harpole et al. (2011) and in Table 1. While these categories are commonly used in literature, what each category implies in terms of formalism of nutrient interaction remains unclear. In particular, we aim here to understand which categories are prevented and which ones are more or less promoted by the interaction formalism assumed. To this end, we provided a theoretical framework of $\mathrm{N}$ and $\mathrm{P}$ fertilization experiments based on the computation of ratios between plant demand and soil supply for each of the two nutrients. The theoretical analysis is developed for two mathematical formalisms of interaction (LM or $\mathrm{MH}$ ). This allowed us to define, for each formalism, the correspondence between Harpole categories and the values of the limitation by each nutrient when considered alone. Then, we analytically investigated how the choice of formalism modifies the NP limitation.

Finally, we applied our framework to the case of nutrient limitations in croplands. The justification of this choice is twofold: first, nutrient limitation is a key question in croplands at the global scale. Croplands can be over-fertilized but this concerns only few countries in the World. For example, global P fertilizer application in 2005 averaged around $10 \mathrm{kgP} / \mathrm{ha} / \mathrm{yr}$ but with a large continental variability: $\sim 25 \mathrm{~kg} / \mathrm{ha} / \mathrm{yr}$ in Europe vs $\sim 3 \mathrm{~kg}$ P/ha in Africa (Liu et al., 2008). MacDonald et al. (2011) showed that $30 \%$ of cropland are characterized by negative soil $\mathrm{P}$ budget. Additional studies have established that nutrient-limitation is a major limitation for croplands at regional (Guilpart et al., 2017; Schils et al., 2018) or at the global scale, besides water limitation. For instance, Mueller et al. (2012) estimated that $\sim 70 \%$ of the cropland where potential yield is not achieved at the global scale could close their yield gap by solely focusing on nutrient inputs. The second major reason for focusing on croplands is that experiments with single and combined $\mathrm{N}$ and $\mathrm{P}$ fertilizer applications (as defining "fertilization experiments") are not common enough in croplands to provide a global picture of $\mathrm{N}$ and $\mathrm{P}$ limitation based solely on observations, contrary to what was done in natural ecosystems (Elser et al., 2007; Harpole et al., 2011). Indeed, in cropland, fertilization experiments are usually characterized by an one-time addition for N (Di Paolo \& Rinaldi, 2008; Salvagiotti et al., 2008) while for P, the same amount of fertilizer is applied each year for decades in so-called long-term field experiments with crops responding both to the annual supply of fertilizer and to the cumulative effect on soil P availability (e.g., Bai et al. (2013)). This makes deciphering the contribution of each nutrient difficult. Moreover, in such experiments, many $\mathrm{P}$ treatments are tested and for a given treatment, the same amount of fertilizer is applied each year for decades, which makes the limitation in the long-term trial somehow non-representative to the nutrient limitation happening in the surrounding fields. When an one-time application is the focus of a study, it is usually difficult to retrieve the application level before the experiment (e.g., Deguchi 
Table 1

Nutrient Limitation Categories Defined in Harpole et al. (2011) and for Each Category, Theoretical Conditions Required for $R_{N}$ and $R_{P}$ to Make an Ecosystem in This Category and its Occurrence at the Global Scale for Maize

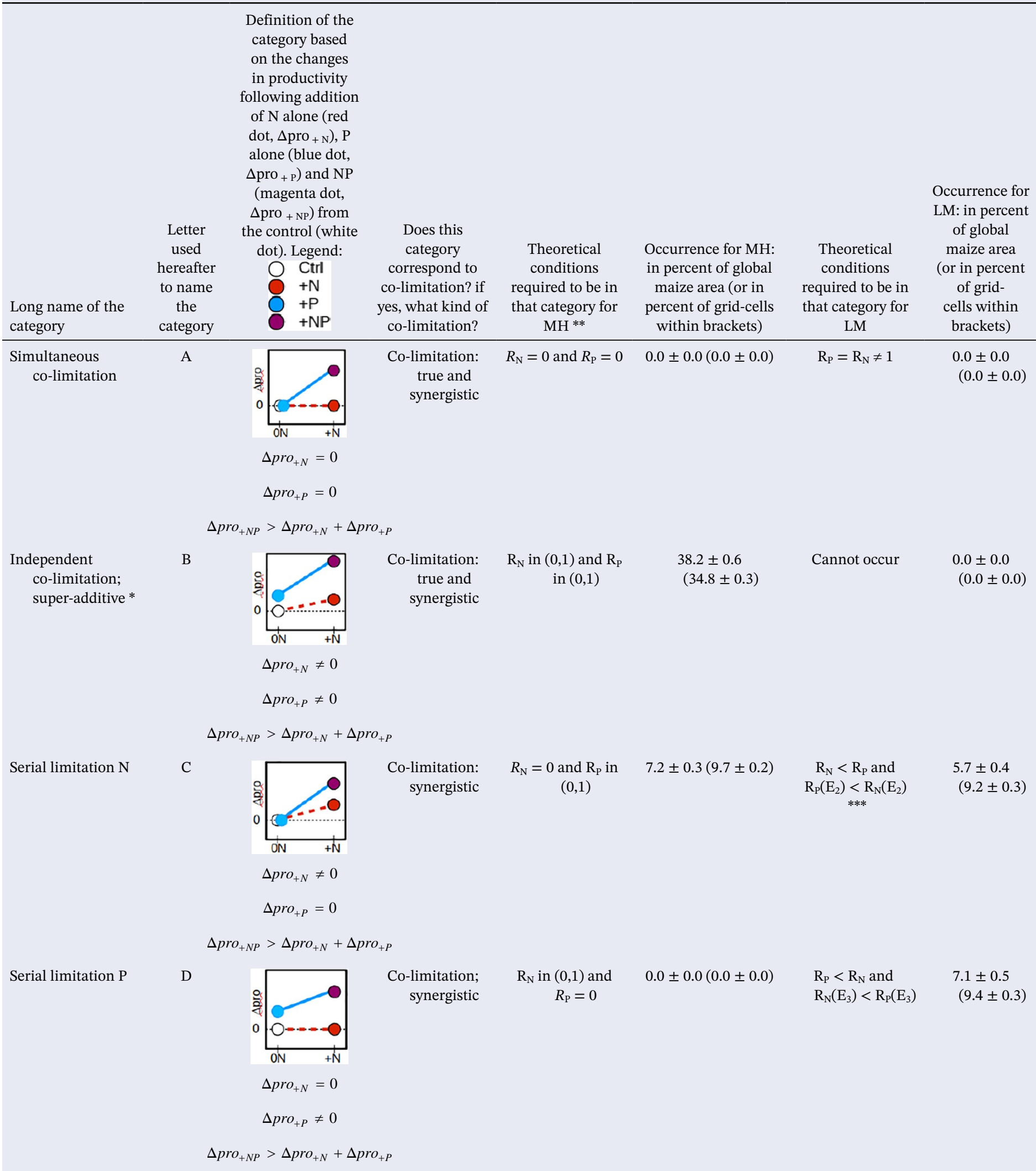


Table 1

Continued

\begin{tabular}{|c|c|c|c|c|c|c|c|}
\hline $\begin{array}{l}\text { Long name of the } \\
\text { category }\end{array}$ & $\begin{array}{l}\text { Letter } \\
\text { used } \\
\text { hereafter } \\
\text { to name } \\
\text { the } \\
\text { category }\end{array}$ & $\begin{array}{c}\text { Definition of the } \\
\text { category based } \\
\text { on the changes } \\
\text { in productivity } \\
\text { following addition } \\
\text { of } \mathrm{N} \text { alone (red } \\
\text { dot, } \Delta \text { pro }+\mathrm{N} \text { ), } \mathrm{P} \\
\text { alone (blue dot, } \\
\Delta \text { pro }+ \text { P) and NP } \\
\text { (magenta dot, } \\
\Delta \text { pro }+ \text { NP) from } \\
\text { the control (white } \\
\text { dot). Legend: } \\
\text { Ctrl } \\
+\mathrm{N} \\
+\mathrm{P} \\
+\mathrm{NP}\end{array}$ & $\begin{array}{l}\text { Does this } \\
\text { category } \\
\text { correspond to } \\
\text { co-limitation? if } \\
\text { yes, what kind of } \\
\text { co-limitation? }\end{array}$ & $\begin{array}{l}\text { Theoretical } \\
\text { conditions } \\
\text { required to be in } \\
\text { that category for } \\
\text { MH ** }\end{array}$ & $\begin{array}{l}\text { Occurrence for MH: } \\
\text { in percent of global } \\
\text { maize area (or in } \\
\text { percent of grid-cells } \\
\text { within brackets) }\end{array}$ & $\begin{array}{l}\text { Theoretical } \\
\text { conditions } \\
\text { required to be in } \\
\text { that category for } \\
\text { LM }\end{array}$ & $\begin{array}{l}\text { Occurrence for } \\
\text { LM: in percent } \\
\text { of global } \\
\text { maize area } \\
\text { (or in percent } \\
\text { of grid- } \\
\text { cells within } \\
\text { brackets) }\end{array}$ \\
\hline \multirow[t]{5}{*}{$\begin{array}{l}\text { Single-resource } \\
\text { response } \mathrm{N}\end{array}$} & \multirow[t]{5}{*}{$\mathrm{E}$} & $\$$ & \multirow[t]{5}{*}{ No co-limitation } & \multirow[t]{5}{*}{$\begin{array}{c}\mathrm{R}_{\mathrm{N}} \text { in }[0,1) \text { and } \\
R_{\mathrm{P}}=1\end{array}$} & \multirow[t]{5}{*}{$\begin{array}{l}31.2 \pm 0.6 \\
(40.7 \pm 0.4)\end{array}$} & \multirow[t]{5}{*}{$\begin{array}{l}\mathrm{R}_{\mathrm{N}}<\mathrm{R}_{\mathrm{P}} \text { and } \\
\mathrm{R}_{\mathrm{P}}\left(\mathrm{E}_{2}\right) \geq \mathrm{R}_{\mathrm{N}}\left(\mathrm{E}_{2}\right) \\
\quad * * * *\end{array}$} & \multirow[t]{5}{*}{$\begin{array}{l}40.3 \pm 0.7 \\
(53.2 \pm 0.5)\end{array}$} \\
\hline & & ON $+N$ & & & & & \\
\hline & & $\Delta \operatorname{pro}_{+N} \neq 0$ & & & & & \\
\hline & & $\Delta$ pro $_{+P}=0$ & & & & & \\
\hline & & ${ }_{+N P}=\Delta p r o_{+N}+\Delta p$ & & & & & \\
\hline \multirow[t]{5}{*}{$\begin{array}{l}\text { Single-resource } \\
\text { response P }\end{array}$} & $\mathrm{F}$ & 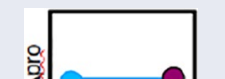 & \multirow[t]{5}{*}{ No co-limitation } & \multirow[t]{5}{*}{$R_{\mathrm{N}}=1 \underset{[0,1)}{\text { and } R_{\mathrm{P}} \text { in }}$} & \multirow[t]{5}{*}{$7.5 \pm 0.5(3.6 \pm 0.1)$} & \multirow[t]{5}{*}{$\begin{array}{l}\mathrm{R}_{\mathrm{P}}<\mathrm{R}_{\mathrm{N}} \text { and } \\
\mathrm{R}_{\mathrm{N}}\left(\mathrm{E}_{3}\right) \geq \mathrm{R}_{\mathrm{P}}\left(\mathrm{E}_{3}\right)\end{array}$} & \multirow[t]{5}{*}{$\begin{array}{l}31.1 \pm 0.8 \\
(17.1 \pm 0.5)\end{array}$} \\
\hline & & ON + + & & & & & \\
\hline & & $\Delta p r o_{+N}=0$ & & & & & \\
\hline & & $\Delta p r o_{+P} \neq 0$ & & & & & \\
\hline & & $+N P=\Delta p r o_{+N}+\Delta p$ & & & & & \\
\hline \multirow[t]{5}{*}{ No response } & G & 원 & \multirow[t]{5}{*}{ No co-limitation } & \multirow[t]{5}{*}{$R_{\mathrm{N}}=1$ and $R_{\mathrm{P}}=1$} & \multirow[t]{5}{*}{$\begin{array}{l}15.8 \pm 0.4 \\
(11.1 \pm 0.2)\end{array}$} & \multirow[t]{5}{*}{$R_{\mathrm{N}}=1$ and $R_{\mathrm{P}}=1$} & \multirow[t]{5}{*}{$\begin{array}{c}15.8 \pm 0.4 \\
(11.1 \pm 0.2)\end{array}$} \\
\hline & & ON & & & & & \\
\hline & & $\Delta p r o_{+N}=0$ & & & & & \\
\hline & & $\Delta p r o_{+P}=0$ & & & & & \\
\hline & \multicolumn{2}{|c|}{$\Delta \operatorname{pro}_{+N P}=\Delta \operatorname{pro}_{+N}+\Delta p r o_{+P}$} & & & & & \\
\hline
\end{tabular}

Columns 1, 3, 4 define each category and are based on Harpole et al. (2011). Columns 5 and 7 give the conditions in terms of $R_{N}$ and $R_{P}$ (i.e., the limitations in the control experiment) required to be in each category. This is the result of our theoretical framework. Columns 6 and 8 give the occurrence of each category for maize at the global scale and are the results of our modeling approach. Both results of the theoretical framework and modeling approach are given for two formalisms of interaction: multiple limitation hypothesis (MH, columns 5 and 6) and Liebig's law of minimum (LM, columns 7 and 8).

* the category B is restricted in this study to synergistic cases (called "super-additive" in Harpole et al., 2011) while non-synergistic cases (called "sub-additive" or "additive" in Harpole et al., 2011) can happen. Such non-synergistic co-limitations are allowed neither by MH nor by LM (Text (S1). ** a parenthesis instead of a square bracket used in an interval means that the corresponding endpoint is excluded from the interval; for example, $\mathrm{R}$ in $[0,1)$ means $0 \leq R<1$. $* * *$ corresponds to " $\mathrm{E}_{1}: \mathrm{N}$-limited and $\mathrm{E}_{2}$ : P-limited". **** corresponds to " $\mathrm{E}_{1}: \mathrm{N}$-limited and ( $\mathrm{E}_{2}: \mathrm{N}$-limited or NP-limited or not limited at all)". 


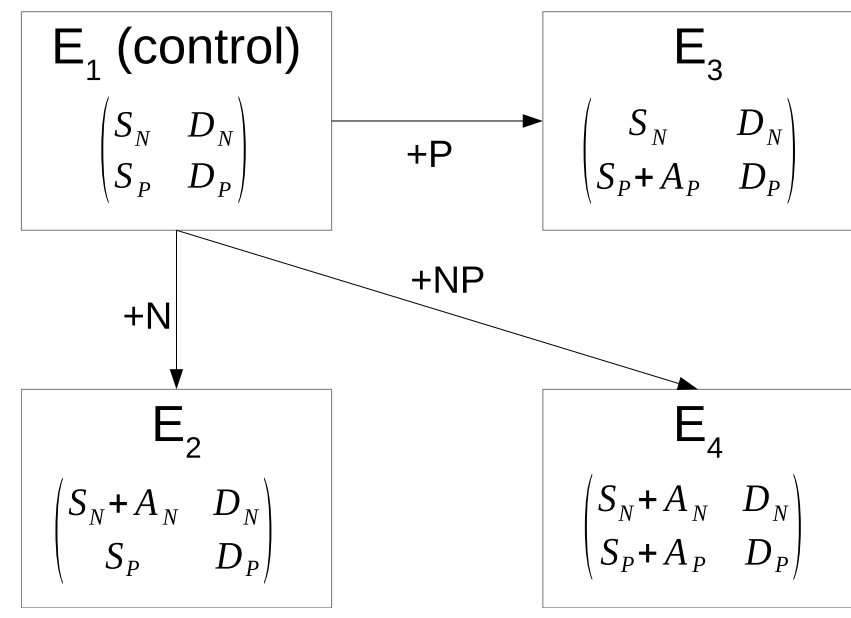

Figure 1. Schematic representation of the fertilization experiments. The different experiments (called $\mathrm{E}_{1}-\mathrm{E}_{4}$ ) vary as function of their supply of $\mathrm{N}\left(\mathrm{S}_{\mathrm{N}}\right.$ or $\left.\mathrm{S}_{\mathrm{N}}+\mathrm{A}_{\mathrm{N}}\right)$ and $\mathrm{P}\left(\mathrm{S}_{\mathrm{P}}\right.$ or $\left.\mathrm{S}_{\mathrm{P}}+\mathrm{A}_{\mathrm{P}}\right)$ with $\mathrm{S}_{\mathrm{X}}$ : soil supply in the CTRL experiment and $A_{X}$ : increase in soil supply following the addition of fertilizer, for the nutrient $\mathrm{X}$ with $\mathrm{X}$ in $\{\mathrm{N}, \mathrm{P}\}$. For a given nutrient $\mathrm{X}, \mathrm{D}_{\mathrm{X}}$ is the demand in this nutrient and is similar in all experiments. et al., (2017); Restelatto et al., (2017)), which prevents an accurate definition of the control in these cases. Thus, here, we develop a theoretical analysis, that is particularly suited to investigating nutrient limitations in cropland. We applied our framework on global spatially explicit computations of soil supply and plant demand of $\mathrm{N}$ and $\mathrm{P}$ for croplands to achieve their potential yield, in order to assess the occurrence of co-limitation in croplands for each interaction formalism. Potential yield is here defined as the theoretical yield achieved without limitations of water and nutrients and without pest/diseases. Thus, water limitation is not considered in the following study and we come back on this point in the discussion.

\section{Theoretical Framework}

Based on a framework commonly used in global studies (Goll et al., 2012; Kvakić et al., 2018), we characterized the limitation of a nutrient considered alone as the ratio (R) of its soil supply (S) and the demand by the plant to achieve its potential biomass (D):

$$
\begin{aligned}
& R_{N}=\min \left(1, \frac{S_{N}}{D_{N}}\right) \\
& R_{P}=\min \left(1, \frac{S_{P}}{D_{P}}\right)
\end{aligned}
$$

where $S_{X}$ and $D_{X}$ correspond to the supply and demand of the nutrient $\mathrm{X}$, respectively (in $\mathrm{kgX} / \mathrm{ha} / \mathrm{yr}$ ) with $\mathrm{X}$ is in $\{\mathrm{N}, \mathrm{P}\}$. A ratio $\mathrm{R}$ close to 0 means a very high limitation while a ratio close to 1 means no limitation. We prevent $\mathrm{R}$ to be greater than 1 as we studied limitation that cannot happen when supply is greater than demand.

Single and combined fertilization experiments are a common tool to assess nutrient limitation on a given site. They correspond to changes in nutrient supply in different combinations from the control ( $\left.\mathrm{E}_{1}\right)$ : addition of $\mathrm{N}$ alone $\left(\mathrm{E}_{2}\right), \mathrm{P}$ alone $\left(\mathrm{E}_{3}\right)$ or $\mathrm{N}$ and $\mathrm{P}$ together $\left(\mathrm{E}_{4}\right)$ (Figure 1). Based on the above equations defining the limitations of $\mathrm{N}$ and $\mathrm{P}$ (Equations 1 and 2, respectively), theses changes in nutrient supply translate into limitations of each nutrient for each experiment $\mathrm{E}$ as follows:

$$
\begin{aligned}
& \mathrm{E}_{1}: R_{N}\left(E_{1}\right)=\min \left(1, \frac{S_{N}}{D_{N}}\right) \text { and } R_{P}\left(E_{1}\right)=\min \left(1, \frac{S_{P}}{D_{P}}\right) \\
& \mathrm{E}_{2}: R_{N}\left(E_{2}\right)=\min \left(1, \frac{S_{N}+A_{N}}{D_{N}}\right) \text { and } R_{P}\left(E_{2}\right)=\min \left(1, \frac{S_{P}}{D_{P}}\right) \\
& \mathrm{E}_{3}: R_{N}\left(E_{3}\right)=\min \left(1, \frac{S_{N}}{D_{N}}\right) \text { and } R_{P}\left(E_{3}\right)=\min \left(1, \frac{S_{P}+A_{P}}{D_{P}}\right) \\
& \mathrm{E}_{4}: R_{N}\left(E_{4}\right)=\min \left(1, \frac{S_{N}+A_{N}}{D_{N}}\right) \text { and } R_{P}\left(E_{4}\right)=\min \left(1, \frac{S_{P}+A_{P}}{D_{P}}\right)
\end{aligned}
$$

with $\mathrm{A}_{\mathrm{N}}$ and $\mathrm{A}_{\mathrm{P}}$ corresponding to the increase of $\mathrm{N}$ and $\mathrm{P}$ soil supply following addition of $\mathrm{N}$ and $\mathrm{P}$, respectively.

In the above framework, each nutrient is considered alone while the two nutrients interact. An ecosystem is thus defined by its NP limitation, called $\mathrm{R}_{\mathrm{NP}}$ in the following. Two formalisms of interaction have been 


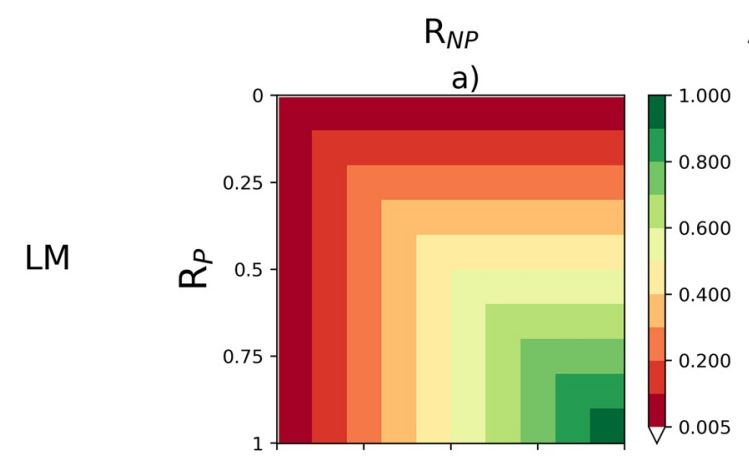

b)

$\mathrm{MH}$

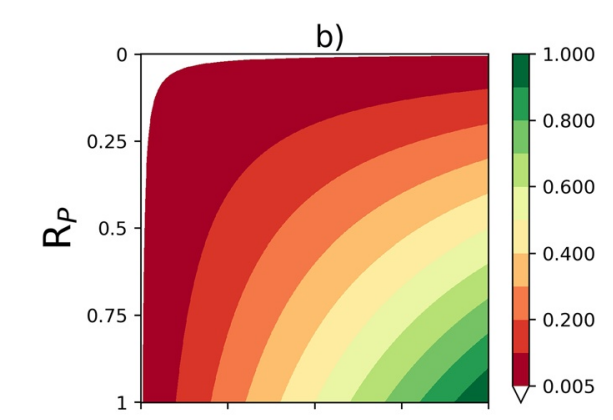

c)

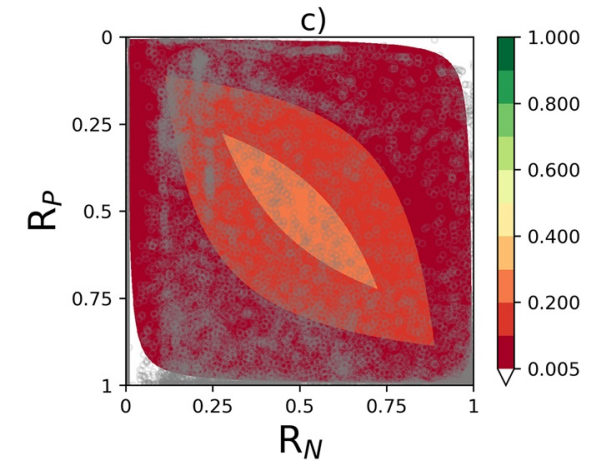

$\Delta \mathrm{R}_{N}$ to make $\mathrm{R}_{N P}=0.75$

d)

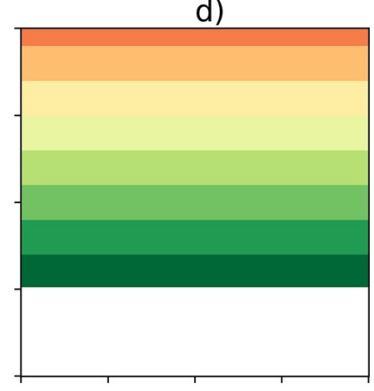

e)
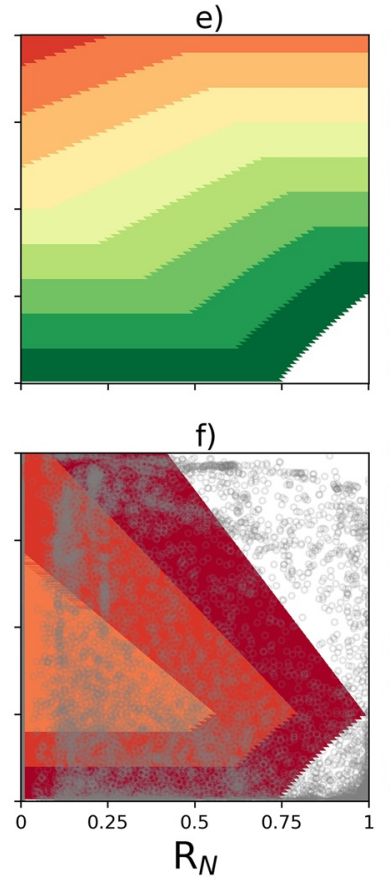

$\Delta \mathrm{R}_{P}$ to make $\mathrm{R}_{N P}=0.75$

g)
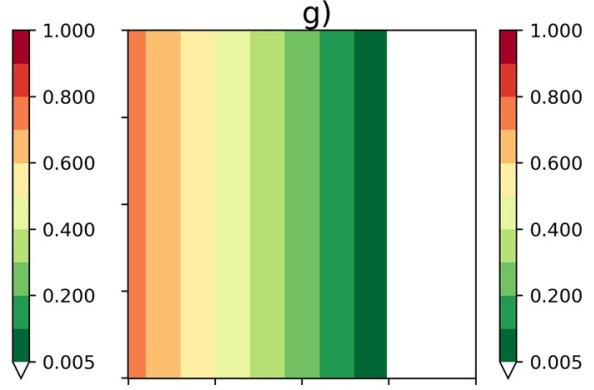

h)

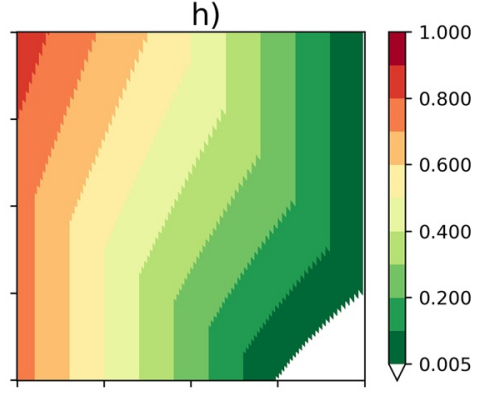

i)

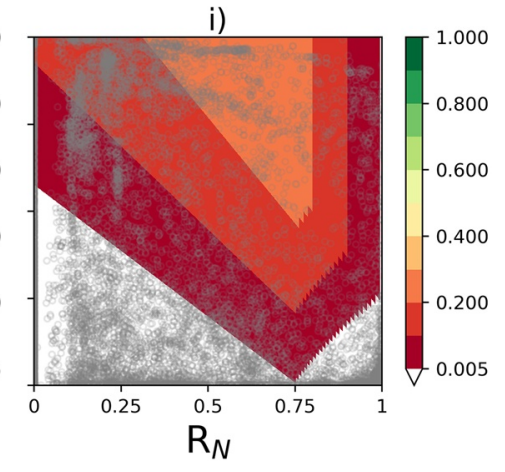

Figure 2. $R_{N P}, \Delta R_{N}$ and $\Delta R_{P}$ for any values of $R_{N}$ ( $x$-axis) and $R_{P}$ ( $y$-axis). $\Delta R_{N}$ and $\Delta R_{P}$ corresponds to change in $R_{N}$ and $R_{P}$ required at the same time to make $\mathrm{R}_{\mathrm{NP}}$ equal to 0.75 . Each variable is provided for the two formalisms of interaction (LM - first line - and MH - second line) as well as for the difference LM-MH (last line). Note that the colorbar was inverted in panels d,e,g,h to show large values of $\Delta R_{N}$ and $\Delta R_{P}$ in red. White area in each panel correspond to values between 0 and 0.001 . Gray transparent dots in panels c,f,i correspond to all grid-cells considered for maize in our modeling approach.

here considered to compute $\mathrm{R}_{\mathrm{NP}}$ from $\mathrm{R}_{\mathrm{N}}$ and $\mathrm{R}_{\mathrm{P}}$ : multiple limitation hypothesis (called $\mathrm{MH}$ in the following, Equation 7) or Liebig's law of the minimum (called LM hereafter, Equation 8):

$$
\begin{gathered}
R_{N P_{-} M H}\left(E_{i}\right)=R_{N}\left(E_{i}\right) \cdot R_{P}\left(E_{i}\right) \\
R_{N P_{-} L M}\left(E_{i}\right)=\min \left(R_{N}\left(E_{i}\right), R_{P}\left(E_{i}\right)\right)
\end{gathered}
$$

where $E_{i}$ is the experiment $i$. In $\mathrm{MH}$, the limitations when the nutrients are considered independently $\left(\mathrm{R}_{\mathrm{N}}\right.$ and $\mathrm{R}_{\mathrm{P}}$ ) are multiplied to compute the NP limitation while in LM, the smallest one is selected.

We analytically investigated to which extent the choice of the formalism has an effect on the value of $R_{N P}$ for a given $\left(R_{N}, R_{P}\right)$ couple (Figures $\left.2 a-2 c\right)$. We also investigated how the formalism modulates the increases in $R_{N}$ and $R_{P}$ required to alleviate the NP limitation (here represented by an increase in $R_{N P}$ to reach an arbitrary value of 0.75 ) (Figures $2 \mathrm{~d}-2 \mathrm{i}$ ). Such increases are called $\Delta \mathrm{R}_{\mathrm{N}}$ and $\Delta \mathrm{R}_{\mathrm{P}}$ in the following. $\Delta \mathrm{R}_{\mathrm{N}}$ and $\Delta \mathrm{R}_{\mathrm{P}}$ corresponds to the smallest increase in $\mathrm{R}_{\mathrm{N}}$ and $\mathrm{R}_{\mathrm{P}}$ required at the same time to make $\mathrm{R}_{\mathrm{NP}}$ equal to 0.75 


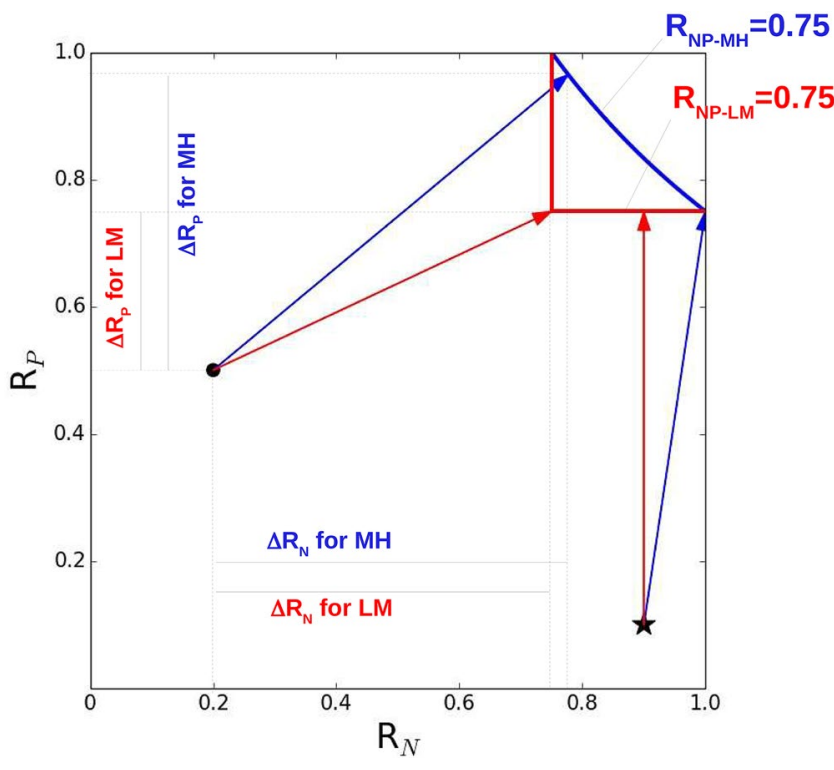

Figure 3. Schematic representation of the computation of $\left(\Delta R_{N}, \Delta R_{P}\right)$. $A$ given grid-cell is defined by its $\left(\mathrm{R}_{\mathrm{N}}, \mathrm{R}_{\mathrm{P}}\right)$ in the plan characterized by the base $\left(\vec{R}_{N}, \vec{R}_{P}\right)$. For a given grid-cell and a given formalism, we called $\vec{u}$ the shortest vector linking $\left(\mathrm{R}_{\mathrm{N}}, \mathrm{R}_{\mathrm{P}}\right)$ and the curve (or segments) defining $R_{\mathrm{NP}}=0.75$. We called $\mathrm{x}$ and $\mathrm{y}$ the compounds of $\vec{u}$ in the base $\left(\vec{R}_{N}, \vec{R}_{P}\right)$, that is, $\vec{u}=\left(\begin{array}{l}x \\ y\end{array}\right)$. We defined $\Delta R_{N}=\max (0, x)$ and $\Delta R_{P}=\max (0, y)$. In the above figure, two grid-cells are provided as an example $\left(R_{\mathrm{N}}=0.2 ; R_{\mathrm{P}}=0.5\right)$ for the black dot, and $\left(R_{\mathrm{N}}=0.9 ; R_{\mathrm{P}}=0.1\right)$ for the black star. The formalism of interaction defines the $\left(\mathrm{R}_{\mathrm{N}}, \mathrm{R}_{\mathrm{P}}\right)$ couples that make $R_{\mathrm{NP}}=0.75$ : the blue curve defines $R_{\mathrm{NP}}=0.75$ for $\mathrm{MH}$ while the two orthogonal red segments define $R_{\mathrm{NP}}=0.75$ for LM. $\vec{u}$ is provided for each grid-cell and each formalism (blue arrow for $\mathrm{MH}$; red arrow for $\mathrm{LM}$ ). We explicitly plotted the $\Delta \mathrm{R}_{\mathrm{N}}$ and $\Delta \mathrm{R}_{\mathrm{P}}$ for the black dot and the two formalisms (solid black lines). Note that for the grid-cell symbolized by the black star, $\Delta R_{N}=0$ for LM.
(Figure 3). We found that the largest differences in $\mathrm{R}_{\mathrm{NP}}$ between the $\mathrm{LM}$ and $\mathrm{MH}$ mathematical formulations are obtained for comparable $\mathrm{R}_{\mathrm{N}}$ and $\mathrm{R}_{\mathrm{P}}$ values $\left(\mathrm{R}_{\mathrm{N}} \sim \mathrm{R}_{\mathrm{P}}\right)$ and both within [0.25-0.75] (Figure $2 \mathrm{c}$ ). In fact, $\mathrm{x}$ in [0.25-0.75] and $\mathrm{x} \sim \mathrm{y}$ mathematically maximize the difference between $\mathrm{x} . \mathrm{y}$ and $\min (\mathrm{x}, \mathrm{y})$. In addition, the largest differences in $\Delta R_{N}$ between $\mathrm{LM}$ and $\mathrm{MH}$ occur for $\mathrm{R}_{\mathrm{N}}<\mathrm{R}_{\mathrm{P}}$ and both $\mathrm{R}_{\mathrm{N}}$ and $\mathrm{R}_{\mathrm{P}}$ lower than 0.75 (Figure 2f). Symmetric results are obtained for $\Delta R_{P}$ (Figure 2i).

In fertilization experiments, nutrient limitation is assessed by looking at the change in productivity ( $\Delta$ pro) according to the addition of $\mathrm{P}$ alone $\left(\Delta\right.$ pro $\left._{+\mathrm{P}}\right), \mathrm{N}$ alone $\left(\Delta \mathrm{pro}_{+\mathrm{N}}\right)$ or $\mathrm{N}$ and $\mathrm{P}$ together $\left(\Delta \mathrm{pro}_{+\mathrm{NP}}\right) . \Delta$ pro is here not expressed in absolute change but relatively to the potential productivity (i.e., without any limitation). Harpole et al. (2011) defined different categories of limitation when considering the two nutrients in interaction. Each category is entirely defined by: (a) the character null or non-null of $\Delta$ pro $_{+\mathrm{N}}$ and $\Delta \mathrm{pro}_{+\mathrm{P}}$ and (b) the relationship between $\Delta$ pro $_{+\mathrm{NP}}$ and $\left(\Delta \mathrm{pro}_{+\mathrm{N}}+\Delta \mathrm{pro}_{+\mathrm{P}}\right)$ (i.e., either $\Delta$ pro $_{+N P}>\Delta$ pro $_{+N}+\Delta p r o_{+P}$ or $\left.\Delta p r o_{+N P}=\Delta p r o_{+N}+\Delta p r o_{+P}\right) . \mathrm{N}$ and $\mathrm{P}$ are the only ones limiting factors considered: we assumed that other nutrients (as water) are not limiting. Following Harpole et al. (2011), a co-limitation is a synergistic relationship, that is, there is co-limitation when the increase in productivity following the addition of $\mathrm{N}$ and $\mathrm{P}$ together is strictly greater than the sum of increases in productivity when each nutrient is added alone (i.e., $\Delta$ pro $_{+N P}>\Delta$ pro $_{+N}+\Delta p r o_{+P}$ ). A given co-limitation is in addition considered as true if the responses to $+\mathrm{N}$ and $+\mathrm{P}$ are either both equal to 0 (i.e., $\Delta$ pro $_{+N}=0$ and $\Delta$ pro $_{+P}=0$, simultaneous co-limitation, category A in Table 1) or both non-null (i.e., $\Delta p r o_{+N} \neq 0$ and $\Delta p r o_{+P} \neq 0$, independent co-limitation, category B). In other cases (i.e., the ecosystem responses differently to the addition of $\mathrm{N}$ and $\mathrm{P}$ alone, for example, $\Delta$ pro $_{+N}=0$ and $\Delta$ pro $_{+P} \neq 0$ ), the co-limitation cannot be considered as true and is only qualified of synergistic (categories $\mathrm{C}$ and $\mathrm{D}$ in Table 1). Non-synergistic relationship (i.e., $\Delta$ pro $_{+N P}=\Delta p r o_{+N}+\Delta p r o_{+P}$ ) concerns the absence of co-limitation: single-resource response (either $\mathrm{N}$ or $\mathrm{P}$ ) or no limitation at all (categories E, F and $\mathrm{G}$ in Table 1).

Here, we assumed that the change in productivity following the addition of $+\mathrm{N},+\mathrm{P}$ or $+\mathrm{NP}$ is equal to the change in $\mathrm{R}_{\mathrm{NP}}$ following the nutrient addition, that is,:

$$
\begin{gathered}
\Delta \operatorname{pro}_{+N}=R_{N P}\left(E_{2}\right)-R_{N P}\left(E_{1}\right) \\
\Delta \operatorname{pro}_{+P}=R_{N P}\left(E_{3}\right)-R_{N P}\left(E_{1}\right) \\
\Delta \operatorname{pro}_{+N P}=R_{N P}\left(E_{4}\right)-R_{N P}\left(E_{1}\right)
\end{gathered}
$$

where $E_{i}$ is the experiment $i$ (Figure 1). This is a key assumption in our approach based on two simplifications described in details in the following. First, through these equations, we assumed that the productivity of a given experiment is proportional to $\mathrm{R}_{\mathrm{NP}}$ and that the slope of this relationship is equal to 1 . In fact, a slope equal to one is not necessary to develop the theoretical analysis described in Text S1. As mentioned before, Harpole categories are defined through (a) the character null or non-null of $\Delta$ pro $_{+\mathrm{N}}$ and $\Delta$ pro $_{+\mathrm{P}}$ and (b) the relationship between $\Delta \mathrm{pro}_{+\mathrm{NP}}$ and $\left(\Delta \mathrm{pro}_{+\mathrm{N}}+\Delta \mathrm{pro}_{+\mathrm{P}}\right)$. These definitions are true even if the productivity of each experiment (and thus the different $\Delta$ pro) is divided by the same slope. We keep here a slope equal to 1 for the sake of simplicity. Second, Equations 9-11 also imply that the relationship of proportionality between the productivity and $\mathrm{R}_{\mathrm{NP}}$ is true for all values of $\mathrm{R}_{\mathrm{NP}}$, in the range [0-1]. In reality, the productivity versus limitation relationship is very likely asymptotic (e.g., Bai et al. (2013)). Here, we may approach this non-linearity by assuming a linear relationship for $\mathrm{R}_{\mathrm{NP}}$ in [0,thresh] where thresh is a given threshold (lower 
than 1); followed by a plateau for $\mathrm{R}_{\mathrm{NP}}$ in [thresh,1]. Note that a plateau corresponds to a slope of 0 for the productivity versus limitation relationship. The correspondence between Harpole categories and the values of $R_{N}$ and $R_{P}$ found at the end of our theoretical analysis are still valid in this more general case, but on the restricted range of $R_{N}$ and $R_{P}$ values between 0 and thresh. In that case, the value 1 used as boundary for $R_{N}$ and $\mathrm{R}_{\mathrm{P}}$ in category definitions-columns 5 and 7 of Table 1 - should be replaced by thresh. For the sake of simplicity, we keep in the following thresh equal to 1 and come back on this point in the Discussion.

As shown in the column 3 of Table 1, each category of Harpole et al. (2011) could be defined as a combination of $\left(\Delta\right.$ pro $_{+N} \neq 0$ or $\Delta$ pro $\left._{+N}=0\right) \mathrm{AND}\left(\Delta\right.$ pro $_{+P} \neq 0$ or $\left.\Delta p r o_{+P}=0\right) \mathrm{AND}\left(\Delta\right.$ pro $_{+N P}>\Delta p r o_{+N}+\Delta$ pro $_{+P}$ or $\left.\Delta p r o_{+N P}=\Delta p r_{+N}+\Delta p r o_{+P}\right)$. We manipulated Equations 1-11 to translate these properties within implications for nutrient limitations in the control, that is, $R_{N}\left(E_{1}\right)$ and $R_{P}\left(E_{1}\right)$. This allowed us to translate, for each interaction formalism (Equation 7 or 8), the Harpole category definition into conditions on $R_{N}\left(E_{1}\right)$ and $R_{P}\left(E_{1}\right)$. This means that we are able to define most Harpole categories in terms of limitation of each nutrient considered alone in the control experiment. $R_{N}\left(E_{1}\right)$ and $R_{P}\left(E_{1}\right)$ are respectively called $R_{N}$ and $R_{P}$ in the following. The equation manipulation is described in details in Text S1 for both MH and LM. Conclusions of this analysis are summarized in Table 1 (columns 5 for MH and column 7 for LM).

We showed in particular that to belong to the category "independent co-limitation" (category B in Table 1) with $\mathrm{MH}$ formalism, an ecosystem has to be characterized by both $R_{N}$ and $R_{P}$ in $(0,1)$ (a parenthesis instead of a square bracket used in an interval means here that the corresponding endpoint is excluded from the interval; For example, $\mathrm{R}$ in $[0,1)$ means $0 \leq R<1)$. All other categories $(\mathrm{A}, \mathrm{C}-\mathrm{G})$ require at least one ratio equal to 0 or 1 : for example, serial limitation $N$ (category $C$ ) requires $R_{N}$ equal to 0 and $R_{P}$ in $(0,1)$. Categories E,F,G are defined by $\Delta p r o_{+N P}=\Delta p r o_{+N}+\Delta p r o_{+P}$ and we showed that this requires at least one ratio equal to 1 with $\mathrm{MH}$ formalism.

We showed that the formalism LM cannot represent true co-limitation, except in the very specific category A (i.e., $R_{P}=R_{N} \neq 1$ ). We found that synergistic co-limitation alone (categories $C$ and $D$ ) can occur with LM but to be in these categories, the amount of $\mathrm{N}$ (if the control is $\mathrm{N}$ limited) or $\mathrm{P}$ (if the control is $\mathrm{P}$ limited) added in the fertilization experiments should be large enough to remove the initial limitation.

\section{Sensitivity of Co-Limitation Occurrence to the Formalism of Interaction in Croplands at the Global Scale}

\subsection{Methods of Computation of Spatially Explicit $R_{N}$ and $R_{P}$}

We computed spatially explicit maps of $R_{N}$ and $R_{P}$ in croplands $\left(0.5^{\circ}\right.$ latitude $x 0.5^{\circ}$ longitude) based on the computation of nutrient demand and soil supply. We then applied the previously described theoretical framework on these $R_{N}$ and $R_{P}$ values to classify each grid-cell according to Harpole categories for the two interaction formalisms.

The computation of supply and demand maps used to estimate $R_{N}$ and $R_{P}$ are described below and in Table 2. To summarize, plant nutrient demand is based on literature-based nutrient harvest index (i.e., the ratio between the nutrient content of grain and the nutrient content of shoot, considered constant at the global scale) combined with spatially explicit distribution of crop potential yield ( $\left.\mathrm{Y}_{\text {pot }}\right)$ provided by Mueller et al. (2012). The soil $\mathrm{N}$ supply has been estimated by using a soil $\mathrm{N}$ budget taking into account fertilizer (mineral and organic), atmospheric deposition, biological fixation, and losses by ammoniac volatilization (Bouwman et al., 2013). The soil P supply is assessed by a potential root uptake model that accounts for soil $\mathrm{P}$ diffusion and soil $\mathrm{P}$ legacy effects. A steady-state assumption was used for $\mathrm{N}$ in the stabilized organic matter. Differences in the computation of supply between $\mathrm{N}$ and $\mathrm{P}$ can be explained by intrinsic differences of behavior in soils between $\mathrm{N}$ ions $\left(\mathrm{NO}_{3}{ }^{-}\right.$and $\left.\mathrm{NH}_{4}{ }^{+}\right)$and orthosphates ions, which are the major forms of $\mathrm{N}$ and $\mathrm{P}$ taken up by plants (Barber et al., 1963). $\mathrm{P}$ is a non-mobile element in soil: ortophosphate ions are easily adsorbed on soil particles which makes its concentration in soil solution very low. In such case, diffusion is the key process of transport in soil. $\mathrm{N}$ is much more mobile; its concentration is usually much higher than $\mathrm{P}$ concentration and mass flow is the major process of $\mathrm{N}$ transport in soil. Given these differences, to representing $\mathrm{P}$ supply requires considering the $\mathrm{P}$ applied in previous years as well as the soil buffering capacity (i.e., the ability of soil to replenish the soil solution). in contrast, $\mathrm{N}$ remaining at the end of the grow- 


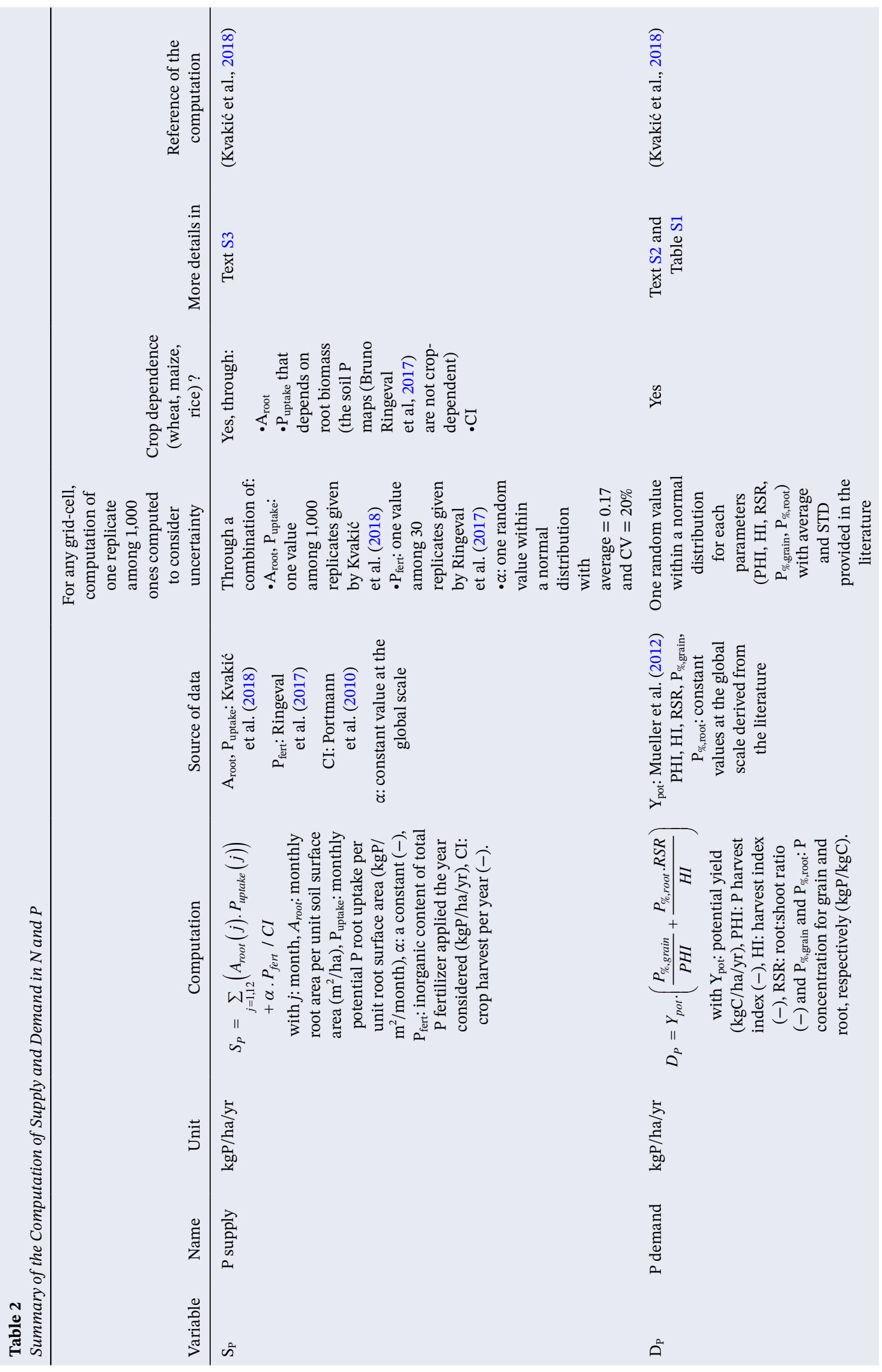




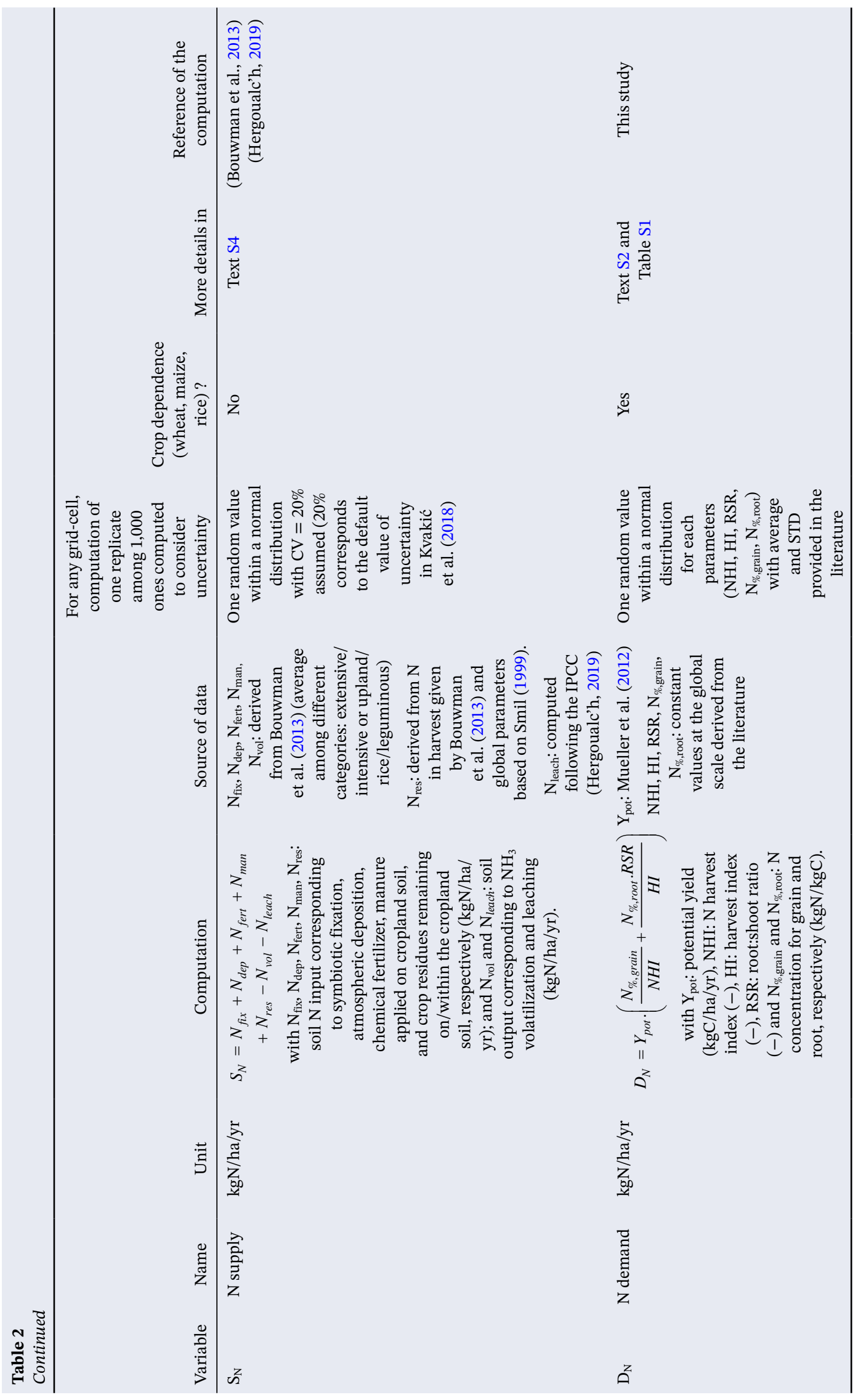


ing season is more likely to be lost through leaching, which prevents us from considering the soil budget of previous years. Supply and demand estimates are representative to a growing season timescale.

Following Kvakić et al. (2018), demands for $\mathrm{N}$ and $\mathrm{P}$ to reach potential yields $\left(\mathrm{D}_{\mathrm{N}}\right.$ and $\mathrm{D}_{\mathrm{P}}$, in $\mathrm{kg}(\mathrm{N}$ or $\mathrm{P}) /$ $\mathrm{ha} / \mathrm{yr}$ ) were derived from the combination of i) non-spatially explicit parameters related to the distribution of carbon (C) and nutrients between the different plant organs at maturity found in the literature and ii) spatially explicit potential yield $\left(\mathrm{Y}_{\text {pot }}\right.$, in $\left.\mathrm{kgC} / \mathrm{ha} / \mathrm{yr}\right)$ :

$$
D_{X}=Y_{\text {pot }} \cdot\left(\frac{X_{\%, \text { grain }}}{X H I}+\frac{X_{\%, \text { root }} \cdot R S R}{H I}\right)
$$

with $\mathrm{X}$ in $\{\mathrm{N}, \mathrm{P}\}$. $\mathrm{XHI}$ corresponds to the nutrient harvest index (no unit), HI is the harvest index (i.e., the ratio between the carbon content of grain and the carbon content of shoot, no unit), RSR is the root/shoot ratio (no unit) and $\mathrm{X}_{\% \text {, grain }}$ and $\mathrm{X}_{\% \text {,root }}$ are nutrient concentrations $(\mathrm{kg}(\mathrm{N}$ or $\mathrm{P}) / \mathrm{kgC})$ for grain and root, respectively. Kvakić et al. (2018) have shown that a XHI-based method provides similar demand estimates compared with other approaches that are based on the nutrient concentration of all plant organs or QUEFTS (Sattari et al., 2014). The definition of the parameters used in Equation 12 (XHI, HI, RSR, $\mathrm{X}_{\% \text {,grain }}, \mathrm{X}_{\% \text {,root }}$ ) is based on nutrient and $\mathrm{C}$ biomass of different plant organs. Spatially constant values are here used for these parameters. In particular, as the aim of our study is to assess nutrient limitation, we used organ concentrations derived from field experiments in stressed conditions in a multitude of climatic and socio-economic environments (van Duivenbooden, (1992) and Table S1). Details about the computation of Equation 12 and the value of parameters involved in this equation are given in Text $\mathrm{S} 2$. The potential yield $\left(\mathrm{Y}_{\text {pot }}\right)$ is provided by Mueller et al. (2012) in tons per hectare. In Mueller et al. (2012), the world grid-cells are divided into climate bins, defined by different combinations of growing degree days and amount of yearly precipitation; and within a climate bin, the potential yield characterizing this bin is defined as the area-weighted 95th percentile of the grid-cell observed yields.

The supply of $\mathrm{P}\left(\mathrm{S}_{\mathrm{P}}\right.$, in $\left.\mathrm{kgP} / \mathrm{ha} / \mathrm{yr}\right)$ corresponds to the sum of a potential root uptake from $\mathrm{P}$ remaining in soils and a prescribed fraction (called $\alpha$ ) of the inorganic content of total P fertilizer applied in the year considered (Kvakić et al., 2018):

$$
S_{P}=\sum_{j=1,12}\left(A_{\text {root }}(j) \cdot P_{\text {uptake }}(j)\right)+\alpha \cdot P_{\text {fert }} / C I
$$

where $j$ is the month, $A_{\text {root }}$ is the monthly root area per unit soil surface area $\left(\mathrm{m}^{2} / \mathrm{ha}\right), P_{\text {utptake }}$ is the monthly potential P root uptake per unit root surface area $\left(\mathrm{kgP} / \mathrm{m}^{2} / \mathrm{month}\right), \alpha$ is constant (unitless), $P_{\text {fert }}$ is the inorganic content of total $\mathrm{P}$ fertilizer applied the year considered $(\mathrm{kgP} / \mathrm{ha} / \mathrm{yr})$, and $C I$ is crop harvest per year (unitless). The monthly potential root uptake per unit root surface area $\left(P_{\text {uptake }}\right)$ is determined by the soil $\mathrm{P}$ availability and its diffusion to the root according to the monthly root length density following Kvakić et al. (2018), Mollier et al. (2008) and Willigen and Noordwijk (1994):

$$
P_{\text {uptake }}(j)=\pi \cdot \Delta z \cdot L_{r v}(j) \cdot D \cdot \frac{\rho^{2}-1}{G(\rho(j), v(j))} \cdot C_{p}
$$

where $\Delta z$ is the soil depth considered $(\mathrm{m}), L_{r v}$ is the monthly root length density $\left(\mathrm{m} / \mathrm{m}^{3}\right), D$ is the coefficient of $\mathrm{P}$ diffusion $\left(\mathrm{m}^{2} /\right.$ month), $C_{P}$ is the mean concentration of orthophosphate ions of the soil solution in $\Delta \mathrm{z}\left(\mathrm{kgP} / \mathrm{m}^{3}\right), G(\rho, \nu)$ is a dimensionless geometric function of a ratio of soil cylinder to root radius $(\rho$, dimensionless) and an uptake of water ( $\nu$, dimensionless). In the case of $\mathrm{P}$, for which diffusion is the main process of transport in soil, $G(\rho, \nu)$ is simplified and depends on $\rho$ only. We consider $\Delta z=0.3 m$ as P availability and root uptake declines substantially below the plow layer (Lynch \& Brown, 2001). The soil solution $\mathrm{P}$ concentration $C_{p}$ was held constant in time and was derived from yearly inorganic labile P provided by Ringeval et al. (2017) following an empirical Freundlich-type relationship described in Kvakić et al. (2018). The global distribution of inorganic labile P was determined by Ringeval et al. (2017), in which a dynamic soil $\mathrm{P}$ model (representing in particular the equilibrium between $\mathrm{P}$ bound on soil particles and labile $\mathrm{P}$ ) was coupled to datasets representing the change in time of soil input/output related to farming practices, atmos- 
pheric deposition, land-use change, erosion, etc., The temporal variation of the size of the inorganic labile $\mathrm{P}$ pool was represented. The inorganic labile $\mathrm{P}$ can accumulate a given year according to both the balance "soil input-soil output" and the soil P dynamic, and can be used by plants in the following years. Thus, we explicitly considered the soil P legacy effect, as it has been shown to be an important process (Ringeval et al., 2014; Sattari et al., 2012). Root characteristics parameters, root biomass at harvest (derived from $\mathrm{Y}_{\text {pot}}$, RSR, and HI) and seasonality in root biomass (varying between 0 and 1 and derived from simulations of one global gridded crop model, LPJmL (Von Bloh et al, 2018)) were combined to compute $L_{r v}$ and $A_{\text {root }}$. As in Kvakić et al. (2018), we assumed that a fraction $(\alpha)$ of the applied fertilizer $\mathrm{P}$ is directly available to the plant in the same growing season, thus bypassing the $\mathrm{P}$ diffusion pathway. A value of 0.17 is used for $\alpha$ (with an uncertainty of 20\%) based on (Balemi \& Negisho, 2012). Further details can be found in the supporting information (Text S3).

For the supply of $\mathrm{N}$, we used a simpler approach justified by the higher mobility of $\mathrm{N}$ in soil than P. We assumed that the transport of $\mathrm{N}$ in soil to the root is not limiting in the case of $\mathrm{N}$ as its larger concentration makes mass flow efficient. Equation 14 could be applied to the uptake of any solute in the soil, but in the case of a solute whose the transport happens through mass flow, the geometry function $G$ depends not only to root geometry $(\rho)$ but also to water uptake $(\nu)$. This would require the representation of water transpiration by plant, which was considered out of the scope of our study. Higher mobility of $\mathrm{N}$ allows us to neglect legacy effects. With the exception of few recent studies (e.g., ten Berge et al., 2019, focusing on sub-Saharan Africa), $\mathrm{N}$ applied in previous years is commonly neglected in global modeling approaches (Bouwman et al., 2017; Conant et al., 2013; Lassaletta et al., 2014; Liu et al., 2010). The supply of $\mathrm{N}$ is calculated from the soil $\mathrm{N}$ input of the year considered (chemical and organic fertilizer, atmospheric deposition, symbiotic fixation, crop residues remaining on/within crop soils) minus losses corresponding to $\mathrm{NH}_{3}$ volatilization and leaching:

$$
S_{N}=N_{f i x}+N_{\text {dep }}+N_{\text {fert }}+N_{\text {man }}+N_{\text {res }}-N_{\text {vol }}-N_{\text {leach }}
$$

where $\mathrm{N}_{\text {fix }}, \mathrm{N}_{\text {dep }}, \mathrm{N}_{\text {fert }}, \mathrm{N}_{\text {man }}, \mathrm{N}_{\text {res }}$ are soil $\mathrm{N}$ inputs corresponding to symbiotic fixation, deposition, chemical fertilizer, manure applied on cropland soil, and crop residues respectively. $\mathrm{N}_{\mathrm{vol}}$ and $\mathrm{N}_{\text {leach }}$ are soil outputs corresponding to $\mathrm{NH}_{3}$ volatilization and leaching. Datasets describing $\mathrm{N}_{\text {fix }}, \mathrm{N}_{\text {dep }}, \mathrm{N}_{\text {fert }}, \mathrm{N}_{\text {man }}$, and $\mathrm{N}_{\mathrm{vol}}$ were provided by Bouwman et al. (2013). $\mathrm{N}_{\text {res }}$ includes root biomass if the harvest is aboveground and was computed from $\mathrm{N}$ in harvest given by Bouwman et al. (2013) and global parameters (ratios between plant uptake and harvest and between residues remaining on the field and total residues) based on Smil, 1999 (see Text S4). A similar computation was done to estimate $\mathrm{N}$ in crop residues in Liu et al. (2010) and for P in crop residues in Ringeval et al. (2017).

In reality, not all crop residues and manure applied on soil enhances the soil mineral $\mathrm{N}$ at the year of application; only a labile fraction (which depends on the manure type and C:N ratio of the residues) can be used by plants the year of application (Chadwick et al., 2000; Trinsoutrot et al., 2000) while a stable fraction enriches a pool of stabilized $\mathrm{N}$ organic matter. The stabilized organic $\mathrm{N}$ is mineralized in the following years, contributing to enhance the mineral N. Soil organic N consists also in a microbial pool which is connected to the stabilized organic $\mathrm{N}$ and with the mineral $\mathrm{N}$ (immobilization/mineralization). Here, the microbial pool was neglected and we assumed that the stabilized organic matter is in steady-state. This allows us to consider that all crop residues and manure applied on/within the soils a given year reach $\mathrm{S}_{\mathrm{N}}$ without distinguishing the labile versus stable fractions of residues and manure. An assumption of steady-state was also used in Bouwman et al. (2013) and in Liu et al. (2010).

$\mathrm{N}$ leaching was computed following the IPCC (Hergoualc'h, 2019): $\mathrm{N}_{\text {leach }}$ was assumed to be equal to $24 \%$ of input of fertilizer (chemical + manure) for grid-cells where the annual precipitation is greater than annual potential evapotranspiration and null elsewhere. IPCC-computed leaching is likely overestimated but an alternative computation (Wang et al., 2019) had a limited effect on our results (not shown). Annual precipitation and potential evapotranspiration were provided by CRU (Harris et al., 2020).

We recognize that the use of constant parameters at the global scale in the computation of supply and demand is a substantial simplification (Hay, 1995; Sadras, 2006). This is particularly true with respect to plant adjustments to nutrient limitations (Colomb et al., 2007) which are susceptible to modify nutrient organ concentrations. Cultivar diversity also leads to real world differences, for example, for HI. However, 
Table 3

Global Values ( \pm One Standard-Deviation) of the Supply/Demand Ratio (R) for N, P or NP

\begin{tabular}{lccccc}
\hline Nutrient(s) & & $\mathrm{N}$ & $\mathrm{P}$ & $\mathrm{NP}$ (Formalism MH) & NP (Formalism LM) \\
\hline Ratio (R) & Maize & $0.52 \pm 0.00$ & $0.61 \pm 0.01$ & $0.34 \pm 0.00$ & $0.37 \pm 0.01$ \\
& Wheat & $0.60 \pm 0.00$ & $0.72 \pm 0.01$ & $0.47 \pm 0.00$ & $0.49 \pm 0.00$ \\
& Rice & $0.77 \pm 0.00$ & $0.77 \pm 0.01$ & $0.62 \pm 0.01$ & $0.63 \pm 0.01$ \\
\hline
\end{tabular}

The ratio $\mathrm{R}_{\mathrm{NP}}$ is given for the two formalims of interaction: multiple limitation hypothesis $(\mathrm{MH})$ and Liebig's law of minimum (LM).

both plant adjustments (Franklin et al., 2012) and the effect of cultivar diversity on allocation (Folberth et al., 2016) are difficult to represent at the global scale. It is also worth noting that, despite using constant parameters at the global scale, considering grid-cells independently in our uncertainty analysis (see below) made these parameters artificially vary in space.

Each term $\left(S_{N}, D_{N}, S_{P}, D_{P}\right)$ is spatially explicit at half-degree resolution. We took an uncertainty associated with the supply and demand variables into account. To do this, we computed 1,000 replicates for each variable $\left(S_{N}, D_{N}, S_{P}, D_{P}\right)$ by considering different sources of uncertainty (Table 2). Grid-cells are considered independently within each replicate. These replicates were then used pairwise to compute 1,000 replicates for $\mathrm{R}_{\mathrm{N}}, \mathrm{R}_{\mathrm{P}}$ and $\mathrm{R}_{\mathrm{NP}}$. For each ratio, an average and a standard-deviation among these replicates were computed for each grid-cell and were plotted as 2D maps in Supporting Figures. In addition, two values are given to provide information at the global scale: the average and the standard-deviation of the 1,000 global averages. Each global average is computed by using the grid-cell crop area (Ramankutty et al., 2008) as weight. Maize, rice and wheat are considered in this study (see the crop-dependent terms in Table 2) and the ratios computed are representative of the year 2000 . Only grid-cells for which $\mathrm{R}_{\mathrm{P}}$ and $\mathrm{R}_{\mathrm{N}}$ could be computed are considered, which determines the crop area and the global crop production considered in our study (Table S2). In the Main Text, a specific focus is made on maize because it is the most widespread crop across latitudes.

\subsection{Effects of Formalism Choice on Global NP Limitation}

Spatial distributions of $R_{N}, R_{P}$ as well as $R_{N P}$ computed with both formalisms are described and discussed in Text S5. The relationship between $R_{N P}$ and actual yield gap provided by statistical approaches $\left(\mathrm{Y}_{\text {real }} / \mathrm{Y}_{\text {pot }}\right.$, with Yreal being the actual yield) has been investigated at country scale (Text S6). The uncertainty at the grid-cell scale, arising from the uncertainty in the datasets and equation parameters, is larger for $\mathrm{P}$ than for $\mathrm{N}$ (Fig. S4), which reflects the large uncertainty in the P supply (Table S3). Nevertheless, the uncertainty regarding global values remains small (Table 3). Given the large uncertainty at grid-cell scale, we did not focus our analysis on the exact distribution of $R_{N}$ and $R_{P}$. Instead, we assess how the choice of formalism has an effect on $\mathrm{R}_{\mathrm{NP}}, \Delta \mathrm{R}$ and the occurrence of Harpole categories at the global scale. Obviously, the effect of formalism choice on the global values of $\mathrm{R}_{\mathrm{NP}}, \Delta \mathrm{R}_{\mathrm{N}}$ and $\Delta \mathrm{R}_{\mathrm{P}}$ depends on the distribution of grid-cells in the $\left(R_{N}, R_{P}\right)$ space (gray dots in Figures $2 c, 2 f$ and $\left.2 i\right)$. Even though significant, the difference between LM and $\mathrm{MH}$ in global $\mathrm{R}_{\mathrm{NP}}$ is small (Table 3). This is explained by a small number of grid-cells ( 3\%) characterized by conditions that maximize the difference between the LM and MH mathematical formulations (i.e., comparable $\mathrm{R}_{\mathrm{N}} \sim \mathrm{R}_{\mathrm{P}}$ and both within [0.25-0.75], see above). Finally, $\sim 60 \%$ of the grid-cells are characterized by a difference LM-MH smaller than the uncertainty computed with a given formalism ( $\mathrm{LM}$ or $\mathrm{MH}$ ).

The global averages of $\Delta \mathrm{R}$ computed with $\mathrm{MH}\left(\Delta \mathrm{R}_{\mathrm{N}}=0.36 \pm 0.00, \Delta \mathrm{R}_{\mathrm{P}}=0.30 \pm 0.01\right)$ are larger than those computed with $\operatorname{LM}\left(\Delta \mathrm{R}_{\mathrm{N}}=0.30 \pm 0.00, \Delta \mathrm{R}_{\mathrm{P}}=0.26 \pm 0.01\right)$. Numbers provided correspond to averages and standard-deviations among 1,000 replicates of global averaged $R_{N}$ and $R_{P}$. It was analytically shown (Figure 2) that the LM-MH difference of $\Delta R_{P}$ is maximal for a combination of small $R_{P}$ and medium $R_{N}$, as encountered in the center of the USA (Text S5 and Figure S4). Large differences are also noticeable in regions with high limitations of both nutrients, such as the Western Russian Federation and Ukraine. 

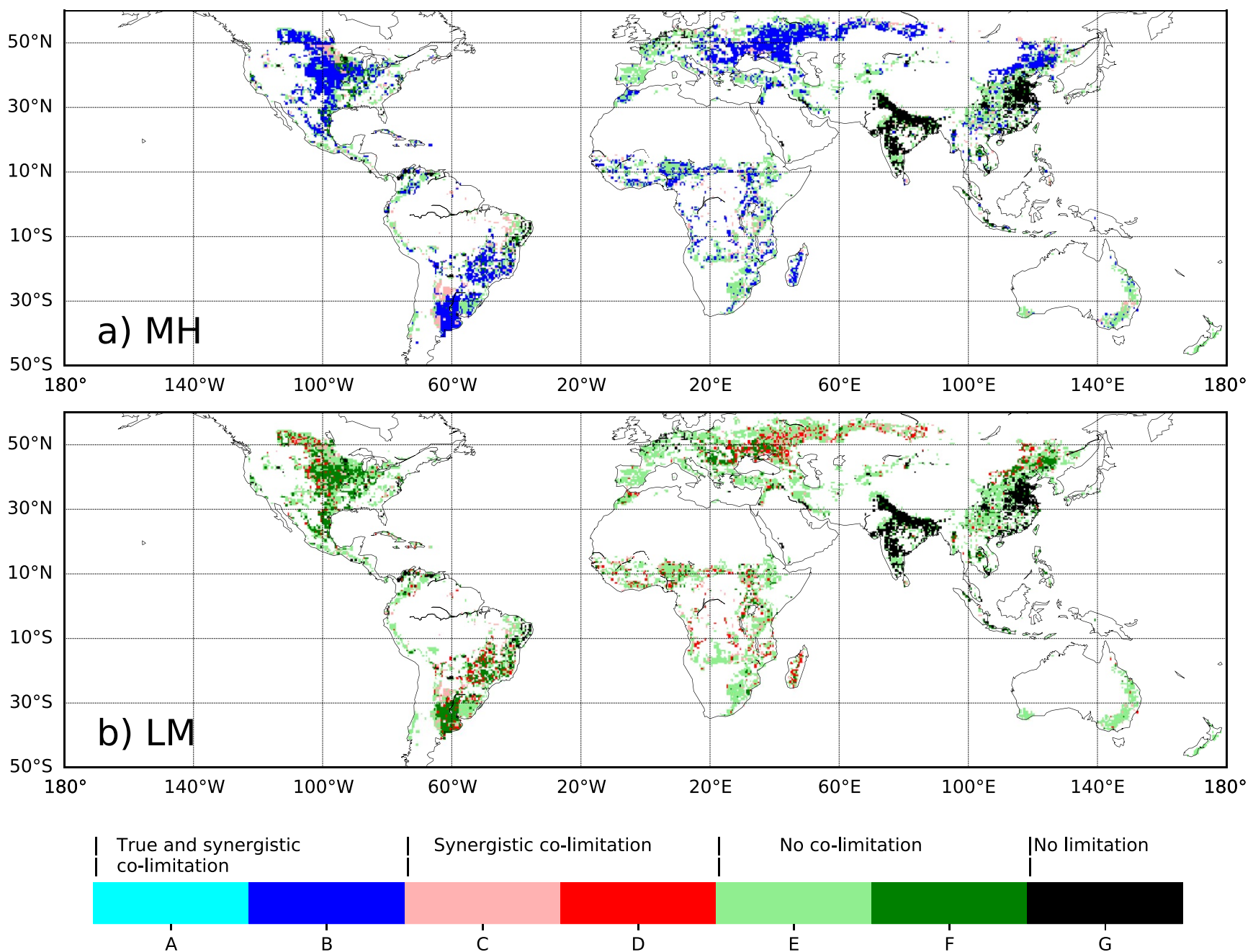

Figure 4. Spatial distribution of the categories defined in Table 1 and in Harpole et al. (2011) for multiple limitation hypothesis (MH, panel (a)) and Liebig's law of minimum (LM, (b)) for maize. Category A corresponds to simultaneous co-limitation, category B to independent co-limitation (super-additive), categories $\mathrm{C}$ and $\mathrm{D}$ to serial limitation ( $\mathrm{N}$ and $\mathrm{P}$, respectively), categories $\mathrm{E}$ and $\mathrm{F}$ to single-resource response ( $\mathrm{N}$ and $\mathrm{P}$, respectively) and category $\mathrm{G}$ to no response. The same color (but with different shades: light and dark) has been chosen for the different categories within each co-limitation type: true and synergistic co-limitation (blue), synergistic co-limitation (red) and no co-limitation (green). For LM, whether one grid-cell belongs either to category C (light red) or to category $\mathrm{E}$ (light green) depends on the increase in soil $\mathrm{N}$ supply following the $\mathrm{N}$ fertilizer addition in the fertilizing experiment (called $\mathrm{A}_{\mathrm{N}}$ in Equations 3-6). The same reasoning applies for categories D (dark red) and F (dark green) with the increase in soil P supply following the addition of $\mathrm{P}$ fertilizer ( $\mathrm{A}_{\mathrm{P}}$ in Equations 3-6).

\subsection{Effects of Formalism Choice on Occurrence of Harpole Categories}

We computed the occurrence of each Harpole category by using conditions in terms of $\mathrm{R}_{\mathrm{N}}$ and $\mathrm{R}_{\mathrm{P}}$, as described in Table 1. We checked that these occurrences are equal to the occurrences found when: modeling fertilization experiments are performed, $\mathrm{R}_{\mathrm{NP}}$ are computed for each experiment (Equations 7 and 8 ) and Equations 9-11 are then applied. The increase of $\mathrm{N}$ and $\mathrm{P}$ supply $\left(\mathrm{A}_{\mathrm{N}}\right.$ and $\left.\mathrm{A}_{\mathrm{P}}\right)$ in fertilization experiments are here equal to $30 \mathrm{kgN} / \mathrm{ha} / \mathrm{yr}$ and $5 \mathrm{kgP} / \mathrm{ha} / \mathrm{yr}$, respectively and are spatially homogeneous for all cropland around the World. While our theoretical framework was initially developed for productivity (Section 3.2), we applied it here to cropland yield, which is consistent with the assumption of fixed harvest index as described in Section 3.1.

With the formalism $\mathrm{MH}$, we found that true co-limitation occurs in $38.2 \pm 0.6 \%$ of the global crop area for maize, via independent co-limitation (category B in Table 1). This category is found in the USA, South America, the Western Russian Federation and Ukraine (Figure 4a). As showed theoretically, to belong to 
that category a crop has to be characterized by both $\mathrm{R}_{\mathrm{N}}$ and $\mathrm{R}_{\mathrm{P}}$ in $(0,1)$. In our simulations, these conditions occur for $\sim 38 \%$ of the maize crop area. Synergistic co-limitation alone (categories $\mathrm{C}$ and $\mathrm{D}$ ) occurs for $6.8 \pm 0.3 \%$ of the global maize crop area and this is only explained by serial limitation $\mathrm{N}$ (category $\mathrm{C}$, dark blue in Figure 4a): no serial limitation $\mathrm{P}$ was found in our numerical application. This can be explained by the fact that $R_{P}$ (contrary to $R_{N}$ ) is never null in our simulations because of the soil $P$ legacy taken into account in our approach (Ringeval et al., 2017). This also prevents simultaneous co-limitation (A) from being found. The occurrence of true co-limitation at the global scale varies between crops $(38.2 \pm 0.6 \%$ for maize, $30.6 \pm 0.4 \%$ for wheat and $14.8 \pm 0.8 \%$ for rice, not shown). Except for few regions (e.g., India), grid-cells where the three crops are grown belong to the same limitation category for all crops (not shown): the difference in occurrence of co-limitation between crops is mainly explained by the crop-specific global distribution.

As theory shows (Text S1), the formalism LM cannot represent true co-limitation, except in the very specific category $A$ (i.e., $R_{P}=R_{N} \neq 1$ ), which is never encountered in our study (Figure $4 b$ and Table 1). We found that synergistic co-limitation alone (categories $\mathrm{C}$ and $\mathrm{D}$ ) can occur in more than $12 \%$ of the global maize area with LM. However, this number is sensitive to the amount of $\mathrm{N}$ and $\mathrm{P}$ added in the fertilization experiments (called respectively $A_{N}$ and $A_{P}$ in Figure 1). For example, a cropland which is initially P-limited is classified in the category $\mathrm{D}$ if the amount of $\mathrm{P}$ added $\left(\mathrm{A}_{\mathrm{P}}\right)$ is sufficient to remove the $\mathrm{P}$ limitation (i.e., the cropland becomes $\mathrm{N}$ limited); otherwise, it belongs to the category $\mathrm{F}$ (Table 1).

Figure 4 shows that many areas are characterized by the same category whatever the interaction formalism chosen (LM or MH): for example, single-resource limitation N (category E) in Europe, no response to either $\mathrm{N}$ or P or NP additions (category G) in India and west of China. The most noticeable differences between LM and MH appear in areas where MH predicts independent co-limitation (category B) while LM predicts other categories. In particular, $62 \%$ of the global maize area considered as B with $\mathrm{MH}$ belongs to single-resource response $\mathrm{P}$ (category $\mathrm{F}$ ) while $19 \%$ belongs to serial limitation $\mathrm{P}$ (category D) but the partition of $\mathrm{F}$ versus $\mathrm{D}$ depends on the amount of $\mathrm{P}$ added in the fertilizer experiment (called $\mathrm{A}_{\mathrm{P}}$ in Equations 5 and 6). These areas of mismatch between MH and LM encompass USA, South America, the Western Russian Federation and Ukraine (Figure 4). Following these results, real fertilization experiments in these areas would help to choose between LM or MH to best represent nutrient interaction.

\section{Discussion}

Our work clarifies the mathematical conditions in terms of supply/demand ratios required to place an ecosystem into a category of nutrient limitation, as defined by Harpole et al. (2011). In particular, we found that synergistic co-limitation can occur with Liebig's law of the minimum under certain conditions that are functions of the amount of $\mathrm{N}$ and $\mathrm{P}$ added in fertilization experiments, as already suggested by Ågren et al. (2012). While Liebig's law of the minimum is based on the limitation by a single nutrient at a time, it allows synergistic co-limitation to happen, which could be counter-intuitive. We found that, if multiple limitation hypothesis is the most appropriate way to represent nutrient interaction, co-limitation should occur for $\sim 46 \%$ of the maize crop area (38\% of true and synergistic co-limitation $+7 \%$ for synergistic alone co-limitation). The occurrence of true co-limitation in croplands would be of a similar magnitude to those reported for natural ecosystems (28\% in Harpole et al. (2011), 42\% in Augusto et al. (2017)).

More investigations are needed to precise the real occurrence of co-limitation in croplands. To do so, a method based on observations, as performed for natural ecosystems (Harpole et al., 2011), is required. As mentioned in the Introduction, one-time fertilizer applications are not as common in croplands as in natural ecosystems. Or atleast, they exist but are exploitable with difficulties. A huge work is required to select studies that deal with one-time applications for both nutrients (alone and in combination), that provide information about the previous applications (that determines the control), and that are characterized by a control that is representative to the region where the trial occurs. A part of the work has been recently done by (Hou et al., 2020). Contrary to previous meta-analysis of fertilization experiments that focused on natural ecosystems only (Augusto et al., 2017; Elser et al., 2007; Li et al., 2016; Yue et al., 2017), the study of Hou et al. (2020) included cropland. However, it treats exclusively of $\mathrm{P}$ and neither of $\mathrm{N}$ nor of interaction between $\mathrm{N}$ and $\mathrm{P}$. In addition, more work is needed to select studies that can be used based on a well-defined 
and region-representative control. Once these studies have been selected, they can be compiled. If numerous enough, they would tell us if co-limitation is really common in croplands, suggesting for example, that farming practices tend to promote co-limitation. On the opposite, the absence of such co-limitation would suggest that human perturbation of nutrient cycles pushes the crop plant outside of its adaptation capacity. Contrary to what happens in natural ecosystems, change in the plant community cannot occur consecutively to fertilizer application in cropland systems as they are mostly single crop. Thus, co-limitation in cropland should be considered as reflecting plant adaptations, for example: plant can invest nutrient in excess to access the limiting nutrient. And an absence of co-limitation would suggest that plant cannot adapt to perturbations. A map of co-limitation based on real fertilization experiments would be different to the spatial distributions of occurrence found in our study (Figure 4) as each interaction formalism used here remains a rough plant-scale approximation of the balance between few plant adjustments.

The occurrences of the different limitation categories that we provided are a function of the spatial distribution of $\mathrm{R}_{\mathrm{N}}$ and $\mathrm{R}_{\mathrm{P}}$, as posited by our theoretical framework. However, these maps are prone to uncertainty due to simplifications in our modeling approach. As mentioned in Section 3.1, some simplifications are related to the use of constant parameters at the global scale in the computation of supply and demand while plant adjustments and some farming practices are susceptible to modify them. Global changes are also very likely modifying yield and grain composition (e.g., Long et al., 2006; Müller et al., 2014) and this effect was not considered in our study which does not simulate temporal changes in nutrient limitation. Our computation of supply in $\mathrm{N}$ and $\mathrm{P}$ are also prone to large uncertainties. For instance, the root $\mathrm{P}$ uptake model is quite simple. The soil solution $\mathrm{P}$ concentration does not seasonally vary and its relationship with inorganic labile $\mathrm{P}$ describes the long-term equilibrium while seasonal dynamic should be considered, in particular for high fixing capacity soils (e.g., oxisols) or soils that precipitate phosphate (e.g., soils with carbonate). This limitation is evident in our treatment of fertilizer P (see Equation 13 and (Kvakić et al., 2018)). Some key processes that increase P acquisition (Hinsinger et al., 2011) like root branching/architecture, exudates/phosphatase, and mycorrhizae association are also neglected. Our soil supply of $\mathrm{N}$ is very simple and an explicit representation of stabilized $\mathrm{N}$ organic matter and inclusion of microbial $\mathrm{N}$ would be an interesting addition for future research. Also, we consider that all $\mathrm{N}$ available can be used by plants, while it should instead be seen as a pool from which different users (plants, denitrifying bacteria and percolating water) take N. Competition between plants and microbes is only beginning to be implemented in land surface models (Davies-Barnard et al., 2020). Seasonality in N supply could be also considered, as N leaching likely concerns the $\mathrm{N}$ remaining at the end of the growing season and not $\mathrm{N}$ taken up by plants (De Jong et al., 2009). Another simplification is related to the use of potential yield provided by statistical methods based on maximum attainable yield within climate bins (Mueller et al., 2012). Such approaches have difficulty distinguishing irrigated and rainfed crops and thus, the here used $\mathrm{Y}_{\text {pot }}$ could be in fact water-limited in some places (van Ittersum et al., 2013). The statistical methodology has been recently updated to improve the separation between water-limited and irrigated yield potential (Wang et al. 2021). Alternative estimates of potential yield such as the ones simulated by Global Gridded Crop Models are also prone to huge uncertainties (Müller et al., 2017; Ringeval et al., 2021).

In our approach, the limitation of potential yield is computed by considering current farming practices to derive the supply. Current practices could be influenced by other limiting factors: for example, if a crop is water limited, farmers can adapt their practices and reduce their nutrient applications accordingly. Sensitivity tests where the demand would be derived from actual yield (instead of potential yield, as in the Main Text) show that $\mathrm{R}_{\mathrm{NP}}$ slightly increases, from $\sim 0.35$ (as in Table 2 ) to $\sim 0.45$. More interesting, such sensitivity tests could help in the determination of areas where other limiting factors (including water) might play a role (Figure S2). The next step is to consider more limiting factors together with the issue to represent their interaction.

Our theoretical analysis has also few caveats. In particular, we assumed a linear relationship between $\mathrm{R}_{\mathrm{NP}}$ and the productivity of each experiment (Equations 9-11). As underlined in the method section, our conclusions are still valid if we assumed a linear relationship up to a value thresh if thresh replaces one in the definition categories given in Table 1 . The value thresh is nevertheless theoretical because the calculated nutrient limitation $\left(\mathrm{R}_{\mathrm{N}}, \mathrm{R}_{\mathrm{P}}, \mathrm{R}_{\mathrm{NP}}\right)$ has no physical meaning and is disconnected from physical measure of, for example, soil P content (Olsen P, etc.,). The fact that the transition between linear and plateau regimes 
occurs for the same $\mathrm{R}_{\mathrm{NP}}$ ( 1 or thresh) globally should be an acceptable assumption as we took into account the spatial variation in soil properties to compute the soil nutrient supply.

In our analysis, we computed $\Delta \mathrm{R}_{\mathrm{N}}$ and $\Delta \mathrm{R}_{\mathrm{P}}$, that is, the increase in $\mathrm{R}_{\mathrm{N}}$ and $\mathrm{R}_{\mathrm{P}}$ required to increase $\mathrm{R}_{\mathrm{NP}}$ up to 0.75 and assessed how the choice of the interaction formalism has an effect on $\Delta R_{N}$ and $\Delta R_{P}$. The variables $\Delta \mathrm{R}_{\mathrm{N}}$ and $\Delta \mathrm{R}_{\mathrm{P}}$ could be translated to increase in soil supply by considering nutrient demand in each gridcell. However such change in supply cannot be easily translated into a change in fertilizer, since our supply estimates take into account some processes occurring after the fertilizer application: for P, we take into account the dynamics of $\mathrm{P}$ in soil (diffusion and root uptake) while for $\mathrm{N}$, we allow for $\mathrm{NH}_{3}$ volatilization and leaching. Our nutrient requirement calculation is driven solely by nutrient limitation, independently of yield gap, contrary to previous estimates based on: soil quality indicators (with no distinction between $\mathrm{N}$ and P) (Fischer et al., 2012; Pradhan et al., 2015), statistical relationships between fertilizer application and yield (Mueller et al., 2012) or "N uptake gaps" based on yield gap and minimal/maximal values of the physiological N efficiency in aboveground biomass derived from the QUEFTS model (Schils et al., 2018; ten Berge et al., 2019). More generally, our nutrient limitation is not straight connected to the yield gap because the actual yield is not used in our computation. It is interesting to note that our computation of $\Delta R_{N}$ and $\Delta R_{P}$ is based on the minimum "physiological" needs for plants. Behind the multiple limitation's mathematical formalism, an increase in $\mathrm{R}_{\mathrm{NP}}$ can be achieved for different combinations of increases in $\mathrm{N}$ and $\mathrm{P}$ (i.e., for different couples $\left.\left(\Delta \mathrm{R}_{\mathrm{N}}, \Delta \mathrm{R}_{\mathrm{P}}\right)\right)$ : despite non-substitution at the molecular or cellular level (Sinclair \& Park, 1993), one element can partly compensate for the other at the plant scale. Here, we considered only one couple (Figure 3), while external variables such as the price or the ease of access to fertilizers will also influence the farmer's choice and could make him/her select another NP combination. This should be taken into account in future attempts to make link with scenarios of nutrient management and policy more straightforward.

Two formalisms are usually used to characterize multiple element limitation: in Liebig's law of the minimum, plants are generally limited by one nutrient at a time, while plants are generally co-limited in a multiple limitation hypothesis. Our study reveals that the choice of the formalism has only a marginal effect on the estimate of current global NP limitation $\left(\mathrm{R}_{\mathrm{NP}}\right)$ for the cereals considered. This result is explained by the fraction of grid-cells in our approach that is within the area of the $R_{N}$ vs $R_{P}$ space that maximizes the difference between the two formalisms. The formalism choice has a bigger effect on the increases in $R_{N}$ and $R_{P}$ required at the same time to alleviate the NP limitation. Because of very different theoretical founding principles behind each formalism, the use of one or other formalism leads to very different estimates of occurrence of co-limitation (i.e., the occurrence of each category defined in Table 1) in cropland. Our study identifies areas where real fertilization experiments should occur to help choosing between LM or MH to best represent nutrient interaction in croplands. Other option is to go further in the representation of mechanisms of nutrient interaction in models. Indeed, as mentioned earlier, Liebig's law of minimum or multiple limitation hypothesis could be considered as macro-properties that reflect the same processes of plant adjustments but, depending on the context, plant adjustments lead to one or the other formalism (Ågren et al., 2012). It was also stipulated (Farrior et al., 2013) that plants can be limited by only one resource at a time, but that the integration of the different limitations in time makes the plants limited by several resources at the scale of the growing season. In our point of view, the use of mechanistic approaches as the ones based on optimality principles (Franklin et al, 2020) combined with floating C:nutrients ratios (Zaehle \& Dalmonech, 2011) would allow the explicit consideration of some plant adjustments, preventing the need to choose between formalisms.

\section{Conflict of Interest}

The authors declare no conflicts of interest relevant to this study.

\section{Data Availability Statement}

Files corresponding to supply and demand for $\mathrm{N}$ and $\mathrm{P}$ (variables called $\mathrm{S}_{\mathrm{N}}, \mathrm{S}_{\mathrm{P}}, \mathrm{D}_{\mathrm{N}}, \mathrm{D}_{\mathrm{P}}$ in the manuscript) are made available (Ringeval et al., 2021) on the following link: https://doi.org/10.15454/NXYH6G. Computer scripts written by the authors to generate and manipulate files of supply and demand for $\mathrm{N}$ and $\mathrm{P}$ are available upon request to the corresponding author. 
Acknowledgments

This research was supported by the "Institut National de Recherche pour l'agriculture, l'alimentation et l'environment" (INRAE) and the AgroEcoSystem division. The authors thank Lex Bouwman for providing variables at the basis of N supply computation. We thank Thomas A.M. Pugh, Frédéric Barraquand, Alain Mollier, Pascal Denoroy, Pietro Barbieri, Mark Irvine, Tovo Rabemanantsoa and Noémie Schaller for helpful discussion. Finally, the authors would like to thank Aldyth Nys for her assistance with the linguistic aspects of this paper. Modeling and analysis were performed in using Python (Python Software Foundation. Python Language Reference, version 2.7. Available at http://www.python.org).

\section{References}

Achat, D. L., Augusto, L., Gallet-Budynek, A., \& Loustau, D. (2016). Future challenges in coupled C-N-P cycle models for terrestrial ecosystems under global change: A review. Biogeochemistry, 131(1-2), 173-202. https://doi.org/10.1007/s10533-016-0274-9

Ågren, G. I., Wetterstedt, J. Å. M., \& Billberger, M. F. K. (2012). Nutrient limitation on terrestrial plant growth - Modeling the interaction between nitrogen and phosphorus. New Phytologist, 194(4), 953-960. https://doi.org/10.1111/j.1469-8137.2012.04116.x

Augusto, L., Achat, D. L., Jonard, M., Vidal, D., \& Ringeval, B. (2017). Soil parent material-A major driver of plant nutrient limitations in terrestrial ecosystems. Global Change Biology, 23, 3808-3824. https://doi.org/10.1111/gcb.13691

Bai, Z., Li, H., Yang, X., Zhou, B., Shi, X., Wang, B., et al. (2013). The critical soil P levels for crop yield, soil fertility and environmental safety in different soil types. Plant and Soil, 372(1-2), 27-37. https://doi.org/10.1007/s11104-013-1696-y

Balemi, T., \& Negisho, K. (2012). management of soil phosphorus and plant adaptation mechanisms to phosphorus stress for sustainable crop production: A review. Journal of Soil Science and Plant Nutrition, 16.

Barber, S. A., Walker, J. M., \& Vasey, E. H. (1963). Mechanisms for Movement of Plant Nutrients from Soil and Fertilizer to Plant Root. Journal of Agricultural and Food Chemistry, 11(3), 204-207. https://doi.org/10.1021/jf60127a017

Barros, I. d., Williams, J. R., \& Gaiser, T. (2004). Modeling soil nutrient limitations to crop production in semiarid NE of Brazil with a modified EPIC version. Ecological Modelling, 178(3-4), 441-456. https://doi.org/10.1016/j.ecolmodel.2004.04.015

Bouwman, A. F., Beusen, A. H. W., Lassaletta, L., van Apeldoorn, D. F., van Grinsven, H. J. M., Zhang, J., \& Ittersum van, M. K. (2017). Lessons from temporal and spatial patterns in global use of N and P fertilizer on cropland. Scientific Reports, 7, 40366. https://doi. org/10.1038/srep40366

Bouwman, L., Goldewijk, K. K., Van Der Hoek, K. W., Beusen, A. H. W., Van Vuuren, D. P., Willems, J., et al. (2013). Exploring global changes in nitrogen and phosphorus cycles in agriculture induced by livestock production over the 1900-2050 period. Proceedings of the National Academy of Sciences, 110, 20882-20887. https://doi.org/10.1073/pnas.1012878108

Chadwick, D. R., John, F., Pain, B. F., Chambers, B. J., \& Williams, J. (2000). Plant uptake of nitrogen from the organic nitrogen fraction of animal manures: A laboratory experiment. The Journal of Agricultural Sciences, 134(2), 159-168. https://doi.org/10.1017/ S0021859699007510

Colomb, B., Debaeke, P., Jouany, C., \& Nolot, J. M. (2007). Phosphorus management in low input stockless cropping systems: Crop and soil responses to contrasting P regimes in a 36-year experiment in southern France. European Journal of Agronomy, 26(2), 154-165. https:// doi.org/10.1016/j.eja.2006.09.004

Conant, R. T., Berdanier, A. B., \& Grace, P. R. (2013). Patterns and trends in nitrogen use and nitrogen recovery efficiency in world agriculture. Global Biogeochemical Cycles, 27(2), 558-566. https://doi.org/10.1002/gbc.20053

Davidson, E. A., \& Howarth, R. W. (2007). Nutrients in synergy. Nature, 449(7165), 1000-1001. https://doi.org/10.1038/4491000a

Davies-Barnard, T., Meyerholt, J., Zaehle, S., Friedlingstein, P., Brovkin, V., Fan, Y., et al. (2020). Nitrogen cycling in CMIP6 land surface models: Progress and limitations. Biogeosciences, 17(20), 5129-5148. https://doi.org/10.5194/bg-17-5129-2020

De Jong, R., Drury, C. F., Yang, J. Y., \& Campbell, C. A. (2009). Risk of water contamination by nitrogen in Canada as estimated by the IROWC-N model. Journal of Environmental Management, 90(10), 3169-3181. https://doi.org/10.1016/j.jenvman.2009.05.034

DeWit,C.(1992). Resource use efficiencyinagriculture.AgriculturalSystems, 40(1-3),125-151.https://doi.org/10.1016/0308-521x(92)90018-j

Deguchi, S., Uozumi, S., Touno, E., Uchino, H., Kaneko, M., \& Tawaraya, K. (2017). White clover living mulch reduces the need for phosphorus fertilizer application to corn. European Journal of Agronomy, 86, 87-92. https://doi.org/10.1016/j.eja.2017.03.006

Di Paolo, E., \& Rinaldi, M. (2008). Yield response of corn to irrigation and nitrogen fertilization in a Mediterranean environment. Field Crops Research, 105(3), 202-210. https://doi.org/10.1016/j.fcr.2007.10.004

Elser, J. J., Bracken, M. E. S., Cleland, E. E., Gruner, D. S., Harpole, W. S., Hillebrand, H., et al. (2007). Global analysis of nitrogen and phosphorus limitation of primary producers in freshwater, marine and terrestrial ecosystems. Ecology Letters, 10(12), 1135-1142. https://doi. org/10.1111/j.1461-0248.2007.01113.x

Farrior, C. E., Tilman, D., Dybzinski, R., Reich, P. B., Levin, S. A., \& Pacala, S. W. (2013). Resource limitation in a competitive context determines complex plant responses to experimental resource additions. Ecology, 94(11), 2505-2517. https://doi.org/10.1890/12-1548.1

Fischer, G., Nachtergaele, F. O., Prieler, S., Teixeira, E., Toth, G., van Velthuizen, H., et al. (2012). Global Agro_ecological Zones (GAEZ ver 3.0), Model documentation. IIASA/FAO.

Folberth, C., Elliott, J., Müller, C., Balkovic, J., Chryssanthacopoulos, J., Izaurralde, R. C., et al. (2016). Uncertainties in global crop model frameworks: Effects of cultivar distribution, crop management and soil handling on crop yield estimates. Biogeosciences Discussions, 1-30. https://doi.org/10.5194/bg-2016-527

Folberth, C., Elliott, J., Müller, C., Balkovič, J., Chryssan-thacopoulos, J., Izaurralde, R. C., et al. (2019). Parameterization-induced uncertainties and impacts of crop management harmonization in a global gridded crop model ensemble. e0221862. In J. M. Martínez-Paz (Ed.), PLOS ONE, 14. https://doi.org/10.1371/journal.pone.0221862

Franklin, O., Harrison, S. P., Dewar, R., Farrior, C. E., Brännström, Å., Dieckmann, U., et al. (2020). Organizing principles for vegetation dynamics. Native Plants, 6(5), 444-453. https://doi.org/10.1038/s41477-020-0655-x

Franklin, O., Johansson, J., Dewar, R. C., Dieckmann, U., McMurtrie, R. E., Brannstrom, A., \& Dybzinski, R. (2012). Modeling carbon allocation in trees: A search for principles. Tree Physiology, 32(6), 648-666. https://doi.org/10.1093/treephys/tpr138

Goll, D. S., Brovkin, V., Parida, B. R., Reick, C. H., Kattge, J., Reich, P. B., et al. (2012). Nutrient limitation reduces land carbon uptake in simulations with a model of combined carbon, nitrogen and phosphorus cycling. Biogeosciences, 9(9), 3547-3569. https://doi. org/10.5194/bg-9-3547-2012

Guilpart, N., Grassini, P., van Wart, J., Yang, H., van Ittersum, M. K., van Bussel, L. G. J., et al. (2017). Rooting for food security in Sub-Saharan Africa. Environmental Research Letters, 12(11), 114036. https://doi.org/10.1088/1748-9326/aa9003

Harpole, W. S., Ngai, J. T., Cleland, E. E., Seabloom, E. W., Borer, E. T., Bracken, M. E. S., et al. (2011). Nutrient co-limitation of primary producer communities. Ecology Letters, 14(9), 852-862. https://doi.org/10.1111/j.1461-0248.2011.01651.x

Harris, I., Osborn, T. J., Jones, P., \& Lister, D. (2020). Version 4 of the CRU TS monthly high resolution gridded multivariate climate dataset. Scientific Data, 7(109). https://doi.org/10.1038/s41597-020-0453-3

Hay, R. K. M. (1995). Harvest index: A review of its use in plant breeding and crop physiology. Annals of Applied Biology, 126, 197-216. https://doi.org/10.1111/j.1744-7348.1995.tb05015.x

Hergoualc'h, K. (2019). Chapter 11: N 2 O Emissions from Managed Soils, and CO 2 Emissions from Lime and Urea Application. In 2019 Refinement to the 2006 IPCC Guidelines for National Greenhouse Gas Inventories. Retrieved from https://www.ipcc-nggip.iges.or.jp/public/2019rf/pdf/4_Volume4/19R_V4_Ch11_Soils_N2O_CO2.pdf 
Hinsinger, P., Brauman, A., Devau, N., Gérard, F., Jourdan, C., Laclau, J.-P., et al. (2011). Acquisition of phosphorus and other poorly mobile nutrients by roots. Where do plant nutrition models fail? Plant and Soil, 348(1-2), 29-61. https://doi.org/10.1007/s11104-011-0903-y

Hou, E., Luo, Y., Kuang, Y., Chen, C., Lu, X., Jiang, L., et al. (2020). Global meta-analysis shows pervasive phosphorus limitation of aboveground plant production in natural terrestrialecosystems. Nature Communications, 11(1), 637. https://doi.org/10.1038/ s41467-020-14492-w

Kvakić, M., Pellerin, S., Ciais, P., Achat, D. L., Augusto, L., Denoroy, P., et al. (2018). Quantifying the Limitation to World Cereal Production Due To Soil Phosphorus Status. Global Biogeochemical Cycles. https://doi.org/10.1002/2017GB005754

Lassaletta, L., Billen, G., Grizzetti, B., Anglade, J., \& Garnier, J. (2014). 50 year trends in nitrogen use efficiency of world cropping systems: The relationship between yield and nitrogen input to cropland. Environmental Research Letters, 9(10), 105011. https://doi. org/10.1088/1748-9326/9/10/105011

Li, Y., Niu, S., \& Yu, G. (2016). Aggravated phosphorus limitation on biomass production under increasing nitrogen loading: A meta-analysis. Global Change Biology, 22(2), 934-943. https://doi.org/10.1111/gcb.13125

Liu, J., You, L., Amini, M., Obersteiner, M., Herrero, M., Zehnder, A. J. B., \& Yang, H. (2010). A high-resolution assessment on global nitrogen flows in cropland. Proceedings of the National Academy of Sciences of the United States of America, 107(17), 8035-8040. https:// doi.org/10.1073/pnas.0913658107

Liu, Y., Villalba, G., Ayres, R. U., \& Schroder, H. (2008). Global Phosphorus Flows and Environmental Impacts from a Consumption Perspective. Journal of Industrial Ecology, 12(2), 229-247. https://doi.org/10.1111/j.1530-9290.2008.00025.x

Long, S. P., Ainsworth, E. A., Leakey, A. D., Nösberger, J., \& Ort, D. R. (2006). Food for thought: Lower-than-expected crop yield stimulation with rising CO. Science, 312. https://doi.org/10.1126/science.1114722

Lynch, J. P., \& Brown, K. M. (2001). Topsoil foraging-an architectural adaptation of plants to low phosphorus availability. Plant and Soil, 237(2), 225-237. https://doi.org/10.1023/a:1013324727040

MacDonald, G. K., Bennett, E. M., Potter, P. A., \& Ramankutty, N. (2011). Agronomic phosphorus imbalances across the world's croplands. Proceedings of the National Academy of Sciences, 108(7), 3086-3091. https://doi.org/10.1073/pnas.1010808108

Mollier, A., De Willigen, P., Heinen, M., Morel, C., Schneider, A., \& Pellerin, S. (2008). A two-dimensional simulation model of phosphorus uptake including crop growth and P-response. Ecological Modelling, 210(4), 453-464. https://doi.org/10.1016/j.ecolmodel.2007.08.008

Mueller, N. D., Gerber, J. S., Johnston, M., Ray, D. K., Ramankutty, N., \& Foley, J. A. (2012). Closing yield gaps through nutrient and water management. Nature, 490(7419), 254-257. https://doi.org/10.1038/nature11420

Müller, C., Elliott, J., Chryssanthacopoulos, J., Arneth, A., Balkovic, J., Ciais, P., et al. (2017). Global gridded crop model evaluation: Benchmarking, skills, deficiencies and implications. Geoscientific Model Development, 10(4), 1403-1422. https://doi.org/10.5194/ gmd-10-1403-2017

Müller, C., Elliott, J., \& Levermann, A. (2014). Fertilizing hidden hunger. Nature Climate Change, 4(7), 540-541. https://doi.org/10.1038/ nclimate 2290

Peñuelas, J., Poulter, B., Sardans, J., Ciais, P., van der Velde, M., Bopp, L., et al. (2013). Human-induced nitrogen-phosphorus imbalances alter natural and managed ecosystems across the globe. Nature Communications, 4. https://doi.org/10.1038/ncomms3934

Portmann, F. T., Siebert, S., \& Döll, P. (2010). MIRCA2000-Global monthly irrigated and rainfed crop areas around the year 2000: A new high-resolution data set for agricultural and hydrological modeling. Global Biogeochemical Cycles, 24(1). https://doi. org/10.1029/2008GB003435

Pradhan, P., Fischer, G., van Velthuizen, H., Reusser, D. E., \& Kropp, J. P. (2015). Closing yield gaps: How sustainable can we be? PloS One, 10(6), e0129487. https://doi.org/10.1371/journal.pone.0129487

Ramankutty, N., Evan, A. T., Monfreda, C., \& Foley, J. A. (2008). Farming the planet: 1. Geographic distribution of global agricultural lands in the year 2000. Global Biogeochemical Cycles, 22(1). https://doi.org/10.1029/2007GB002952

Restelatto, R., Menezes, L. F. G. d., Paris, W., Sartor, L. R., Martin, T. N., Herrera, W. F. B., \& Pavinato, P. S. (2017). Sorghum and black oat forage production and its nutritive value under phosphate levels. Sca, 38(1), 429. https://doi.org/10.5433/1679-0359.2017v38n1p429

Ringeval, B., Augusto, L., Monod, H., van Apeldoorn, D., Bouwman, L., Yang, X., et al. (2017). Phosphorus in agricultural soils: Drivers of its distribution at the global scale. Global Change Biology. https://doi.org/10.1111/gcb.13618

Ringeval, B., Müller, C., Pugh, T. A. M., Mueller, N. D., Ciais, P., Folberth, C., et al. (2021). Potential yield simulated by global gridded crop models: using a process-based emulator to explain their differences. Geoscientific Model Development, 14(3), $1639-1656$.

Ringeval, B., Nowak, B., Nesme, T., Delmas, M., \& Pellerin, S. (2014). Contribution of anthropogenic phosphorus to agricultural soil fertility and food production. Global Biogeochemical Cycles, 28(7), 743-756. https://doi.org/10.1002/2014GB004842

Ryan, M. H., \& Graham, J. H. (2018). Little evidence that farmers should consider abundance or diversity of arbuscular mycorrhizal fungi when managing crops. New Phytologist, 220(4), 1092-1107. https://doi.org/10.1111/nph.15308

Sadras, V. O. (2006). The N:P stoichiometry of cereal, grain legume and oilseed crops. Field Crops Research, 95(1), 13-29. https://doi. org/10.1016/j.fcr.2005.01.020

Salvagiotti, F., Cassman, K. G., Specht, J. E., Walters, D. T., Weiss, A., \& Dobermann, A. (2008). Nitrogen uptake, fixation and response to fertilizer N in soybeans: A review. Field Crops Research, 108(1), 1-13. https://doi.org/10.1016/j.fcr.2008.03.001

Sattari, S. Z., Bouwman, A. F., Giller, K. E., \& van Ittersum, M. K. (2012). Residual soil phosphorus as the missing piece in the global phosphorus crisis puzzle. Proceedings of the National Academy of Sciences, 109(16), 6348-6353. https://doi.org/10.1073/pnas.1113675109

Sattari, S. Z., van Ittersum, M. K., Bouwman, A. F., Smit, A. L., \& Janssen, B. H. (2014). Crop yield response to soil fertility and N, P, K inputs in different environments: Testing and improving the QUEFTS model. Field Crops Research, 157, 35-46. https://doi.org/10.1016/j. fcr.2013.12.005

Schils, R., Olesen, J. E., Kersebaum, K.-C., Rijk, B., Oberforster, M., Kalyada, V., et al. (2018). Cereal yield gaps across Europe. European Journal of Agronomy, 101, 109-120. https://doi.org/10.1016/j.eja.2018.09.003

Sinclair, T. R., \& Park, W. I. (1993). Inadequacy of the Liebig limiting-factor paradigm for explaining varying crop yields. Agronomy Journal, 85(3), 742-746. https://doi.org/10.2134/agronj1993.00021962008500030040x

Sistla, S. A., \& Schimel, J. P. (2012). Stoichiometric flexibility as a regulator of carbon and nutrient cycling in terrestrial ecosystems under change. New Phytologist, 196(1), 68-78. https://doi.org/10.1111/j.1469-8137.2012.04234.x

Smil, V. (1999). Nitrogen in crop production: An account of global flows. Global Biogeochemical Cycles, 13(2), 647-662. https://doi. org/10.1029/1999gb900015

ten Berge, H. F. M., Hijbeek, R., van Loon, M. P., Rurinda, J., Tesfaye, K., Zingore, S., et al. (2019). Maize crop nutrient input requirements for food security in sub-Saharan Africa. Global Food Security, 23, 9-21. https://doi.org/10.1016/j.gfs.2019.02.001 
Trinsoutrot, I., Recous, S., Bentz, B., Linères, M., Chèneby, D., \& Nicolardot, B. (2000). Biochemical Quality of Crop Residues and Carbon and Nitrogen Mineralization Kinetics under Nonlimiting Nitrogen Conditions. Soil Science Society of America Journal, 64(3), 918-926. https://doi.org/10.2136/sssaj2000.643918x

van Duivenbooden, N. (1992). Sustainability in terms of nutrient elements with special reference to West-Africa. CABO-DLO. Retrieved from http://edepot.wur.nl/332997

van Ittersum, M. K., Cassman, K. G., Grassini, P., Wolf, J., Tittonell, P., \& Hochman, Z. (2013). Yield gap analysis with local to global relevance-A review. Field Crops Research, 143, 4-17. https://doi.org/10.1016/j.fcr.2012.09.009

Von Bloh, W., Schaphoff, S., Müller, C., Rolinski, S., Waha, K., \& Zaehle, S. (2018). Implementing the nitrogen cycle into the dynamic global vegetation, hydrology, and crop growth model LPJmL (version 5.0). Geoscientific Model Development, 11(7), 2789-2812. https:// doi.org/10.5194/gmd-11-2789-2018

Wang, X., Müller, C., Elliot, J., Mueller, N. D., Ciais, P., Jägermeyr, J., et al. (2021). Global irrigation contribution to wheat and maize yield. Nature Communications, 12(1), 1235. https://doi.org/10.1038/s41467-021-21498-5

Wang, Y., Ying, H., Yin, Y., Zheng, H., \& Cui, Z. (2019). Estimating soil nitrate leaching of nitrogen fertilizer from global meta-analysis. The Science of the Total Environment, 657, 96-102. https://doi.org/10.1016/j.scitotenv.2018.12.029

Willigen, P. D., \& Noordwijk, M. V. (1994). Mass flow and diffusion of nutrients to a root with constant or zero-sink uptake II. Zero-sink uptake. Soil Science, 157, 171-175. https://doi.org/10.1097/00010694-199403000-00005

Yue, K., Fornara, D. A., Yang, W., Peng, Y., Peng, C., Liu, Z., \& Wu, F. (2017). Influence of multiple global change drivers on terrestrial carbon storage: Additive effects are common. Ecology Letters, 20(5), 663-672. https://doi.org/10.1111/ele.12767

Zaehle, S., \& Dalmonech, D. (2011). Carbon-nitrogen interactions on land at global scales: Current understanding in modeling climate biosphere feedbacks. Current Opinion in Environmental Sustainability, 3(5), 311-320. https://doi.org/10.1016/j.cosust.2011.08.008 